\title{
Yabancı Dil Olarak Türkçe Öğrenen Öğrencilerin Yazdıkları Öyküleyici Metinlerin Bağdaşıklık Görünümlerinin İncelenmesi*
}

\author{
An Analysis With Regards to Coherence of Narrative Texts \\ Written by Learners of Turkish as a Foreign Language
}

\author{
Başak KARAKOÇ ÖZTÜRK**, B. Erdem DAĞISTANLIOĞLU***
}

Öz: Bu araştırmanın amacı, Türkçeyi yabancı dil olarak öğrenen B1 düzeyindeki öğrencilerin yazdıkları öyküleyici metinlerin bağdaşıklık açısından nasıl bir görünüm sergilediğini tespit etmektir. Araştırma durum çalışması olarak desenlenmiş, veri toplama yöntemi olarak doküman incelemesi yöntemi kullanılmıştır. B1 düzeyindeki öğrencilerin öyküleyici bir metin yazabilmek için uygun olduğu düşünülmüş, Çukurova Üniversitesi Türkçe Öğretimi Uygulama ve Araştırma Merkezi ile Adana Bilim ve Teknoloji Üniversitesi Türkçe Öğretimi Uygulama ve Araştırma Merkezinden B1 yeterlilik düzeyinde olan öğrencilerden gönüllülük esasına dayalı olarak seçilen 60 öğrenci çalışma grubunu oluşturmuştur. Öğrencilerden başlatıcı olayın verildiği bir öyküyü tamamlayarak 550-700 sözcükten oluşan bir öykü yazmaları istenmiştir. Öğrencilerin yazdığı öyküleyici metinlerin bağdaşıklık açısından değerlendirilmesinde bağdaşıklığı sağlayan ögeler ölçüt olarak alınmış ve öğrencilerin yazdıkları metinlerde söz konusu bağdaşıklık ögelerini kullanma sıklıkları belirlenmeye çalışılmıştır. Bu amaçla içerik analizi yapılmış, her bir öğrenci tarafından yazılan metin iki araştırmacı tarafından ayrı ayrı değerlendirilmiştir. Öyküleyici metinlerin bağdaşıklık özelliklerini metindilbilimsel açıdan değerlendirebilmek için bağdaşıklığa ilişkin yapılan kuramsal açıklamaları temel alarak bir değerlendirme formu oluşturulmuş ve her öğrencinin yazdığı metin bağdaşıklık ögelerine yer verme niteliği bakımından değerlendirilmiştir.

Anahtar kelimeler: Metindilbilim, bağdaşıklık, öyküleyici metin, yazma becerisi, Türkçenin yabancı dil olarak öğretimi

\begin{abstract}
The aim of this research is to determine what kind of appearance is it in terms of coherence of the narrative texts written by students at level B1 and learn Turkish Language as a foreign one. The research was designed as a case study and document review method was used as data collection method. Students at level B1 was considered suitable for writing narrative texts and the study group consisted of 60 students selected on the basis of volunteerism from them who were at the competence level of B1 from Çukurova University Turkish Language Teaching Research and Application Center, Adana Science and Technology University Turkish Language Teaching Research and Application Center. The students were asked to write a story consisting of 550-700 words by completing a story given the initiator event. The items of coherence were taken as criteria in the evaluation of the narrative texts written by the students in terms of coherence and it was attempted to determine the frequency of usage of coherence items in the texts written by the students. For this purpose, content analysis was done and the text written by each student was evaluated separately by two researchers. An evaluation form was created which was based on theoretical explanations of compatibility in order to evaluate the coherence properties of narrative texts in terms of textlinguistics and each student's text was evaluated in terms of the inclusion of coherence properties.
\end{abstract}

Keywords: Textlinguistics, coherence, narrative text, writing skill, teaching Turkish as a foreign language

\footnotetext{
* Bu araştırma, Çukurova Üniversitesi Bilimsel Araştırma Projeleri Birimi tarafindan desteklenmektedir: SBA-2017-8072.

**Dr. Öğretim Üyesi, Çukurova Üniversitesi, Eğitim Fakültesi Türkçe Eğitimi Ana Bilim Dalı, Adana-Türkiye, eposta: bkarakoc@cu.edu.tr

***Dr. Öğretim Üyesi, Çukurova Üniversitesi, Eğitim Fakültesi Türkçe Eğitimi Ana Bilim Dalı, Adana-Türkiye, eposta: erdemdgstn@gmail.com
} 


\section{Giriş}

Dil öğretimi dört temel dil becerisinin geliştirilmesi üzerine kuruludur. Konuşma, dinleme, okuma ve yazma becerilerinden oluşan dil becerilerinin yetkin bir şekilde kullanılması dil öğretiminin başarıya ulaştığını gösteren en önemli ölçüttür. Dil kullanıcısının dinlediğini ve okuduğunu anlaması ile kendisini yazılı veya sözlü olarak ifade edebilmesi hem ana dilde hem de hedeflenen yabancı dilde ulaşılması istenen amaçlardır. Dil yoluyla ürünler oluşturmanın yani üretmenin göstergelerinden biri olan yazma becerisini geliştirmek yoğun ve uzun bir süreci gerektirdiği için oldukça zor ve zaman alıcıdır. Bununla birlikte yazma yoluyla ortaya konan ürünün anlamlı bir bütünlük arz edip etmemesi yazma becerisinin niteliği hakkında dil eğitimcisine fikir vermektedir.

Çünkü yazma eğitiminde en önemli seviye dil kullanıcısının metin olarak kabul edilebilecek bir dilsel ürün ortaya koymasıdır. Bu bağlamda bir dilsel ürünün metin olup olmadığını belirlemeye çalışan, metinlerin içerik ve bildirişim işlevlerini inceleyen metindilbilimin doğuşunu ve metindilbilimsel gelişmeler içinde metin kavramına yönelik bakış açısının nasıl değiştiğini tartışmak yerinde olacaktır.

\section{Metin Kavramı ve Tümce Ötesi Yaklaşım}

Metin, dil eğitiminde kullanılan önemli bir araçtır. Dil eğitiminde gerçekleştirilen etkinlikler metinleri okuma ve dinleme, okuduğunu veya dinlediğini anlama ile metin üretmeye dayanmaktadır. Metin kavramını köken açısından tanımlamaya çalışmak ise içerdiği derin anlama gönderimde bulunur niteliktedir.

Batı dillerinde kullanılan ve kökeni Latince olan text kavramının Türkçedeki karşılığ metindir. Text Latincedeki texere, textus, textum (dokumak, dokuma, örgü) sözcükleriyle ilişkilidir (Ayata Şenöz, 2005). Dokuma sürecinde nasıl ipliklerin ilmek ilmek dokunması ve bir bütüne ulaşılması söz konusuysa, metnin oluşabilmesi için de cümleleri rastgele bir araya getirmek değil anlamlı bir birliktelik içerisinde var etmek bir nevi anlamı ilmek ilmek dokumak gerekmektedir.

Halliday ve Hasan'a (1976) göre metin anlamın cümleler tarafından gerçekleştirildiği ve cümleler içinde kodlandığı anlamsal bir birliktir. Metin kavramı, Karaağaç (2013, s. 585) tarafından "Kendisini oluşturan söz öbeği ve cümle dizilerinin birbirlerine bağdaşıklık ve tutarlılık ölçekleriyle bağlanarak bir anlam bütünü oluşturdukları, belli bir amaçla üretilmiş, başı ve sonu kesin çizgilerle sınırlandırılmış, yazılı ya da sözlü bir dil ürünüdür." şeklinde tanımlanmıştır. $\mathrm{Bu}$ tanımlardan yola çıkarak metnin anlamlı ve amaçlı bir birlik, yazılı veya sözlü bir dilsel ürün olduğunu söylemek mümkündür. Bununla birlikte bir dil ürününün metin olarak kabul edilmesinde temel koşulun iletişim olduğunu savunan tanımlar da yapılmıştır. De Beaugrande (1985) bir metnin gerçek değerini insanlar arasındaki iletişimsel değeri ile kazandığını belirtmiştir (Akt. Aksan ve Aksan, 1991).

Günay da (2003, s. 35) metni belirli bir bildirişim bağlamında bir ya da birden çok kişi tarafından sözlü ya da yazılı olarak üretilen dil dizgesi olarak tanımlamış; metnin bildirişim değeri taşıyan, devingen bir bütün olduğunu ifade etmiştir. Bu bildirişime örnek olarak yazılı dilsel ürün ile okur-yazar arasındaki iletişim verilebilir. Yazarın yazıp bitirdiği dilsel ürün, okurun onu okumasıyla ve okur-yazar arasında kurulan iletişimle yeniden hayat bulur, canlanır. Yazılarak tamamlandığı varsayılan dilsel üründeki bitmiş̧lik okurun metni anlamlandırma çabasıyla bir başlangıca dönüşür. Öyleyse bu yönüyle metnin, Günay'ın da belirttiği gibi dilin durağan değil, devingen bir süreci olduğu söylenebilir.

Metin kavramının bu derin anlamlı, devingen ve canlı yapısına rağmen dil incelemelerinde yıllarca tümce en büyük dilsel birim olarak görülmüştür. Metin üzerine yapılan ilk çalışmalarda metin, dilsel birimlerin ve cümlelerin belirli bir düzende bir araya gelişi olarak görülmüş, metnin bütünlügünü sağlayan unsurlar ve metin bağlamı göz ardı edilmiştir (Uzun, 1995). Oysaki tümce, tek başına kesin bir yargı bildiren; yapılan işi, oluşu, hareketi anlatan bir görünüme sahip olmakla birlikte, bir dil dizgesi olarak, bütüncül bakıldığında düşüncenin aktarımında yetersiz kalmaktadır (Üstünova, 2002, s. 150-151). Tümceler belli bir bağlam içerisinde kullanıldığından tümcelerin birçok özelliğini içinde bulundukları bağlamsal 
koşullardan yola çıkarak açıklamak olanaklıdır (Ayata Şenöz, 2005). Bir metni oluşturan tümcelerin tek tek anlaşılması metnin bütünündeki anlama ulaşmayı sağlamamakta, bütünün yarattığı bağlama dayalı derinliği yaratmamaktadır. Söylenen ya da yazılan metnin anlamını çözebilmek için metnin kendine özgü dokusunu keşfetmek, bağlama dönük değerlendirmeler yapmak gerekmektedir.

Zaman içerisinde dilbilim alanında yapılan çalışmalarda yalnızca tümceye dayanarak yapılan dilsel incelemelerin yetersiz kaldığ 1 savunulmuş, tümce ötesi ilişkilere yani tümceden daha büyük birimlere yönelmek gerektiği ortaya atılmıştır. Dilbilim araştırmalarında dilin çeşitli durumlara ve amaçlara bağlı oluşu da dikkate alınmış, metinden yola çıkılması gerektiği ve en büyük dilsel birimin tümce değil metin olduğu savunulmuştur (Ayata Şenöz, 2005). Dilbilim alanındaki bu paradigmatik dönüşüm metindilbilimin doğmasını sağlamıştır.

Metindilbilime dayalı dil incelemelerinde, metinde yer alan tümceler değil metni oluşturan dilsel birimler arasındaki tüm bağlantılar incelenir. Metnin bir bütün olarak dil bilgisine ve içeriğine dayalı özelliklerini dikkate almak önemlidir. Metindilbilim bir metni yapısal ve anlamsal bütünlükleri açısından değerlendirerek bu değerlendirme sonucunda metni oluşturan temel unsurları anlamaya yönelen yeni bir yaklaşımdır (Aytaş, 2008, s. 56). Alan'a (1994) göre ise metindilbilim, bir metni metin yapan unsurları, metnin oluşturulmasında kullanılan içyapı ve dış yapıyı, metni daha anlaşılır sağlayan prensipleri belirlemeye çalışan bilim dalıdır.

Diğer bilim dalları, metinlerin her şeyden önce içerikleriyle, hangi bilgileri ilettikleriyle, neyi, nasıl söyledikleriyle ve ne tür bir etki yarattıklarıyla ilgilenmelerine karşın, metindilbilim metinlerin oluşturulmasında etkili olan kuralları, metinlerin üretimi ve iletişimsel işlevleriyle ilgilenir (Fix, 2000, s. 186; Akt. Ayata Şenöz, 2005, s. 58).

Bir metinde yer alan tümcelerin dil bilgisi açısından uygun olup olmadığ 1 dil bilgisi kurallarına göre tespit edilirken, bir metni metin olmayandan çeşitli ölçütleri kullanarak ayırt etmek mümkündür. Bunu yapabilmenin yolu metindilbilim çalışmaları sonucunda ortaya çıkan metinsellik ölçütlerine dikkat etmektir. Beaugrande ve Dressler (1981) de dilsel bir ürünün metin olabilmesi ve bildirişim işlevini yerine getirebilmesi için çeşitli ölçütleri karşılaması gerektiğini vurgularlar. Bu ölçütlerin başında bağdaşıklık ve tutarlılık gelmektedir.

\section{Bağdaşıklık ve Bağdaşıklığın Metindilbilimsel İşlevi}

Bir dil ürününün metin olarak kabul edilebilmesi için bağdaşıklık ve tutarlılık özelliğine sahip olması oldukça önemlidir. Tutarlılık metnin anlam ve mantık bütünlügünü ifade etmekte olup okurun bilişsel yetenekleriyle de ilişkilidir. Beaugrande ve Dressler (1981) tutarlılığı, metin merkezli ve okur merkezli olarak ikiye ayırmışlardır. Metin dikkate alındığında tutarlılık metinde kurulan anlamsal bağdır. Okur merkeze alındığında ise tutarlılık okurun metni anlama sürecine işaret eden bir özelliktir. Okurun metni algılaması, metnin tutarlılığına, sürüp giden bir akışa dayanır (Göktürk, 1988). Bu akışı güçlendiren metinsellik ölçütlerinden biri bağdaşıklıktır.

Bağdaşıklık bir yazının metin olmasını sağlayan metin içi ilişkileri kuran dille ilgili özelliklerin tümünü belirtir (Günay, 2003, s. 57). Kelimeleri veya cümleleri birbirine bağlayarak, dil bilgisine dayalı ilişkiler kurarak metnin tutarlılığına hizmet eder. Ayaz'a (2007) göre ise bağdaşıklık metin içerisindeki anlamsal ve sözdizimsel ilişkilerin, cümlelerin ve cümle üstü yapıların birbirine bağlanması, sıralanması, düzenlenmesidir.

Bağdaşıklık araçları doğru kullanıldığında cümle içinde, cümleler arasında, paragraf içinde, paragraflar arasında kurulan bağlantıları netleştirerek metinde birbirine bağımlı bilgilerin açık olarak anlatılmasa da anlaşılmasını sağlar. Kurduğu anlamsal ilişkiler yoluyla (eksiltili anlatım, değiştirim, gönderim) daha önce ifade edilmiş bir bilginin veya metin biriminin tekrar tekrar ifade edilmesini önler. Metinde, okuyucunun zihninde tamamlayacağı noktaları belirleyerek anlam belirsizliğinin önüne geçer, metnin anlaşılırlığını arttırır (Can, 2014).

Uzun (1995) bağdaşıklığ gönderimsel bağdaşıklık ve biçimsel-sözlüksel bağdaşıklık başlıkları altında incelemiştir. Uzun (1995)'un bağdaşıklık konusunda yaptığı tasnifte gönderimsel bağdaşıklık öncül-bağımsız bağdaşıklık ögeleri (kişi adılları, gösterme adılları, 
dönüşlülük adılları, gösterme sıfatları) ve ardıl-bağımlı bağdaşıklık ögelerinden (iyelik ekleri, belirtme durumu eki, ilgi ekleri, kişi ekleri) oluşmaktadır. Ayrıca biçimsel-sözlüksel bağdaşıklık başlığı altında ise bağlaçlara, değiştirime, sözcük ilişkilerine ve sözlüksel bağdaşıklı̆̆a, eksiltiye, zaman-görünüş ve kipe yer verilmiştir.

Halliday ve Hasan (1976) bağdaşıklığın dil bilgisine dayalı unsurlar veya kelimelerle sağlandığını belirtmişler; bu nedenle dil bilgisi (grammatical) bağdaşıklığı ve sözcük (lexical) bağdaşıklığından bahsetmişlerdir. Halliday ve Hasan bağdaşıklığı şu başlıklar altında incelemişlerdir: Gönderim (reference), Değiştirim (subsititution), Eksiltili yap1 (ellipsis), Bağlama ögeleri (conjuction) ve Sözcük bağdaşıklığı (lexical cohesion).

\section{Gönderim}

Bir metinde herhangi bir sözcüğü veya sözcük grubunu başka bir şekilde ifade etmek için aynı cümle içinde veya diğer cümleler içinde o sözcügün veya sözcük grubunun yerine başka bir sözcük, söz grubu ya da bir ekin kullanılması yoluyla gönderimsel bağdaşıklık sağlanır. Günay’a (2003) göre bir metinde bütünlük içinde, daha önce ve daha sonra aynı sözcük, izlek, kavram ya da düşünce aynı biçimde ya da farklı biçimde yeniden kullanılabilir. Her metinde başka ögelere göre yorumlanabilecek artgönderimsel ve öngönderimsel birimler bulunur.

Art gönderim: Metin içinde bir durum, kişi, nesne ya da olay önce açıkça belirtilir daha sonra aynı durum, kişi, nesne ya da olay yerine farklı bir sözcük, sözcük grubu veya ek kullanılarak gönderimde bulunulur.

Cocuklara büyüklerden fazla emniyet ettiği, onlardan esaslı bir zarar gelmeyeceğini bildiği için miydi, yoksa onların da -kendi ölmüş küçükleri gibi- masum ve müdafaasız mahlûklar olduğunu hissettiği için mi böyle yapıyordu? (R. N. Güntekin, Gamsızın Ölümü) (“Çocuklar” sözcüğüne "onlar” kişi zamiri kullanılarak art gönderim yapılmıştır.)

Ön gönderim: Daha sonra ayrıntılı anlatılacak bir duruma, olaya, kişiye ya da nesneye anlatının başında kısaca yer verilir (Günay, 2003). Bu durum, olay, kişi ya da nesne sonraki cümlede veya cümlelerde okurun anlayabileceği şekilde açıklanır.

Ben on seneden fazla şu kahveye gelir, giderim. Bu oğlan bu kadardı. Elbette askerlik zamanı gelmiştir. Belki yirmi birinden de büyüktür. Sen ne dersin Salim Ağa?

İhtiyar Salim Ağa:

- Allah, Allah! Ahmet'e acır gibi bakmıştı. Bana dün gibi geliyor. (S. F. Abasıyanık, Kestaneci Dostum) ("Bu oğlan" diye ifade edilen kişinin Ahmet olduğu anlaşılmaktadır. "Bu oğlan" ile "Ahmet" arasında ön gönderimsel ilişki vardır.)

Değiştirim: Değiştirim ögesinin işleyişi, metinde kimi kez bir adın, kimi kez bir eylemin, kimi kez de bir ya da birden fazla tümcenin tamamının yerini tutuşuna göre farklılık göstermektedir. $\mathrm{Bu}$ nedenle ada bağl1, eyleme bağlı ve tümceye bağlı değiştirim türleri ortaya çıkmaktadır (Uzun, 1995, s. 63). Yani bir adın, eylemin veya tümcenin aynen tekrar edilmesi yerine böyle, öyle, aynı gibi sözcüklerin o adın, eylemin veya cümlenin yerini alması yoluyla değiştirim yapılmaktadır.

- - Perinin bize zararı dokunmaz, dedi.

- Her giren evvela böyle şeyler söyler ama bir ay oturmaz. (Ö. Seyfettin, Perili Köşk) (Böyle sözcüğü "Perinin bize zararı dokunmaz." cümlesinin yerini alıp değiştirim ögesi olarak kullanılmıştır.)

- Dostluktan filan bahsederken sesleri titriyor gibiydi; yahut onlar böyle zannediyorlard1. (S. Ali, Değirmen) (Böyle sözcügü "seslerinin titremesi" eyleminin yerini alarak değiştirim ögesi olarak kullanılmıştır.) 
Eksiltili yapr: Eksiltili anlatım anlam kaybına yol açmamak koşuluyla, bir tümce içinden zamanla bazı sözcükleri atma işidir ya da kullanılmayışları anlatımda eksikliğe neden olmayacak sözcüklerin düşürülmesidir (Günay, 2003).

- Eklerin düșürülmesi yoluyla eksilti: Erkek çocuklar yeni potinlerini siliyorlar(d1), kızlar birbirlerinin saçlarını düzeltiyorlar(d1), çözülmüş kuşaklarını bağlıyorlar(dı) ve düğmelerini ilikliyorlardı. (R. N. Güntekin, Gamsızın Ölümü)

- Ortak nesnenin düşürülmesi yoluyla eksilti: Gözlerini kaldırıp gelen adamı süzdü, sonra, isteksiz, hatta biraz da ürkekçe: "Nedir, ne istersin?" diye sordu Feridun firçay1 uzattı: "Vaktiyle birisi hediye etmişti, dedi, kıymetli olduğunu söylemişti, acaba hakikaten bir değeri var mı? Bakar mısınız?"

Öbürü merakla (fırçayı) eline aldı, (fırçayı) evirdi, (fırçayı) çevirdi, (fırçayı) salladı, (fırçayı) tırnağıyla kazıdı, sonra geri verdi. (R. H. Karay, Garip Bir Hikâye)

Bağlama ögeleri: Görevli biçimbirimler olan bağlaç ve edatlar, Türkçede birimler arası bağı, türlü anlam ilgileri ile sağlamaktadır. Kelimeleri, kelime gruplarını ve cümleleri birbirlerine bağlayan bağlaçlar, çeşitli anlam ilgileriyle bu birimler arasındaki ilişkiyi ortaya koymaya yararlar: sebep, sıra, zıtlık vb. Bağlaç grupları, görevli kelimeler olarak bağlaçlarla veya bağlaçsız olarak kelimelerin birbirine bağlandığı öbeklerdir (Deny, 1941, s. 636; Gencan, 1979, s. 446; Hatiboğlu, 1982, s. 18; Banguoğlu, 1995, s. 390; Ergin, 2009, s. 352; Korkmaz, 1992, s. 18; Korkmaz, 2009, s. 1091). Özmen (2013, s. 80), bağlama grupları başlığında yalnızca bağlaçlarla kurulan kelime gruplarını ele almıştır. Korkmaz (1992, s. 18; 2009, s. 1091), bağlaç grubu (terkîb-i atfî) başlığı altında atı küsi, perynir ekmek, analı babalı vb. biçim birliklerini de değerlendirmiştir. Bağlaçların birimler arasındaki anlam ilgilerini sağlamasının bir diğer örneği da/de, ve bağlaçlarıyla kurulan ikilemelerdir: yalnız ve yalnız, güldü de güldü vb. (Hatiboğlu, 1982, s. 18; Korkmaz, 1992, s. 18). Bağlaçlarla kurulan kelime grupları yani bağlama grupları, başka kelime ya da kelime gruplarıyla da tamlama ilgisiyle bağlanabilmektedir: küçük ama kullanışlı ev, anne ile babanın görev ve sorumlulukları (Hatiboğlu, 1982, s. 19; Korkmaz, 1992, s. 18). Türkçede bağlaçların yanı sıra edat, zaman zarfi, zarf-fiil gibi başka türlerden ve sınıflardan alınmış unsurlar da bazen cümlede bağlaç olarak kullanılabilmektedir (Korkmaz, 2009, s. 1094). Vardar (2002, s. 31), türemiş bağlaçlar başlığında örneğin, klsacası, öbekleşmiş bağlaçlar başlığında da bunun için, gel gelelim, ne var ki örneklerini vermiştir.

- Bu hadise para meselesini aşırı bir şekilde önemsemesine sebep oldu. Daha doğrusu, bu önemsemeyi son noktasına vardırdı (Tarık Buğra, İbiş’in Rüyası, akt. Korkmaz, 2009, s. 1126).

- Aç kalıyorlar da gelip çamaşır yıkamıyorlar. Bu yüzden Zem zem bacı çok kıymetli (Tarık Buğra, İbiş’in Rüyası, akt. Korkmaz, 2009, s. 1128).

- Bunu Süheylâ Selânik’te sörlerde mektep arkadaşlariyla beraber biliyordu. $\underline{O}$ halde Adnan'ın Belkıs'ı beğendiği ne malûmdu (Mithat Cemal Kuntay, Üç İstanbul, akt. Korkmaz, 2009, s. 1129).

Edatlar görevli biçimbirimler olarak isim ya da isim soylu kelimelerden sonra gelip bunlarla diğer kelime veya kelime gruplarıyla türlü anlam bağları kurarlar (Banguoğlu, 1995, s. 385; Deny, 1941, s. 558; Gencan, 1979, s. 438; Hatiboğlu, 1982, s. 72; Korkmaz, 1992, s. 51; Korkmaz, 2009, s. 1053; Li, 2004, s. 25; Vardar, 2002, s. 120). Her ne kadar kelime düzeyinde olsalar da edatlar, enklitik biçimbirimler olarak ekleşme eğilimi de göstermektedirler: ile > $\{+1 \mathrm{~A}\}$, taḳ1 > da/de (Korkmaz, 2009, s. 1053; Özmen; 1987; Tekin, 1958). Edatlarla oluşturulan kelime grupları (edat grubu), sıfat ya da zarf görevinde kullanılabilmektedir (Korkmaz, 1992, s. 51; Özmen, 2013, s. 100). Türkçede, asıl son çekim edatlarının yanı sıra edat gibi kullanılan ve genellikle biçimce isim tamlaması hüviyetinde olan ögeler de mevcuttur: alt, üst, ön, taraf, ara vd. (Korkmaz, 2009, s. 1084; Li, 2004, s. 31). Edatlar, özellikle zamirlerle oluşturdukları kelime gruplarında, içinde bulunduğu birimin gönderimi ile diğer birim ya da birimler arasında benzerlik, eşitlik, sebep, miktar vd. anlam ilgileriyle bağdaşıklık ögesi olarak görev yapmaktadırlar. 
- Sunacağım bildiride ileri süreceğiniz görüşler tartışmaya açılacaktır. Bildiğiniz gibi bu konu öteden beri tartış1la gelmektedir (Korkmaz, 2009, s. 1126).

- Çünkü insan her şeyden önce yaşamak, maddî varlığını korumak zorunda olan bir varlıktır. Bunun içindir ki ilkin yaşayışını ilgilendiren, bir ihtiyacını gideren şeyi görür (Suut Kemal Yetkin, Denemeler, akt. Korkmaz, 2009, s. 1126).

Sözcük bağdaşıklı̆̆l: Bağdaşıklık ilişkisi kurma yollarından biri de sözcük bağdaşıklığıdır. Halliday ve Hasan (1976, s. 274) gönderimi, eksiltili yapıları, değiştirimi ve bağlama ögelerini dil bilgisi bağdaşıklığı araçları olarak tanımlamışlardır. Dil bilgisi bağdaşıklığı, metindeki öbekler ve tümceler arasında kurulan dil bilgisi bağları metnin bağdaşıklık sergilemesinde önemli rol oynar (Keçik ve Uzun, 2003, s. 30).

Sözcük bağdaşıklığı ise söz varlığının kullanımına yöneliktir. Sözcük bağdaşıklığı sözcügün metin içinde çeşitli şekillerde tekrar edilmesi ve aynı kavram alanından kelime kullanılması yoluyla sağlanabilir. Tekrar yoluyla sözcük bağdaşıklığını sağlamanın yolları bir sözcüğün metnin içinde aynen tekrar edilmesi, eş, yakın veya zıt anlamlısının kullanılması, üst veya genel anlamlısının kullanılmasidır. şunlardır:

Keçik ve Uzun'a (2003, s.33) göre ise sözcük bağdaşıklığg sağlayan ilişkilerin bazıları

- Bir sözcüğün aynen yinelenmesi: Hükümetin enflasyonla mücadelesi sürüyor. Bu y1l alınacak önlemlerle enflasyon inişe geçecek.

- Eşanlamlı ya da yakın anlamlı sözcükleri kullanma: Adamın karısı geçen yıl ölmüş. Eşini çok severmiş adamcağız.

- Üstterim-altanlamlılık içeren sözcükleri kullanma: Meyveyi çok yerim. Özellikle elmayı, portakalı.

- Aynı kökten türemiş farklı sözcük türlerindeki sözcükleri kullanma: Ahmet sınavı başardı. Başarısı tüm ailesini sevince boğdu.

- Aynı kavram alanında sözcükleri kullanma: Okullar iki hafta sonra açılacak. Öğrenciler yeni bir öğretim yılının heyecanını şimdiden yaşamaya başladılar bile.

Halliday ve Hasan (1976) sözcük bağdaşıklı̆̆ını açıklarken sözcükler arasındaki ilişkileri yineleme ve eşdizimlilik olarak iki grupta açıklamışlardır. Yinelemenin çeşitli biçimlerde olabileceğini belirtmişlerdir. Örneğin metinde daha önce kullanılan bir sözcük aynen tekrar edilebileceği gibi başka sözcüklerle eş anlamlılık, yakın anlamlılık veya genel anlamlılık ilişkisi kurabilir.

Eşdizimlilik ise aynı bağlamda kullanılmalarından dolayı ilişkilendirilen sözcüklerin oluşturduğu bağlantıları ifade eder. Yani aynı konularla ilgili olarak yazılan metinlerde bir arada kullanılma eğilimi gösteren sözcükler birbiriyle eşdizimlilik ilişkisi içindedir (Stotsky, 1983). Bir arada kullanılma eğilimi gösteren sözcüklerin anlamsal ortaklıklarıyla tümceler arasında bağlantı kurularak metnin kurgusu oluşmakta, aynı zamanda metin örgüsü, bu sözcükler arasında metne özgü bir anlamsal ortaklık meydana getirmektedir. Bu durum metnin iletişimsel işlevine uygun olarak anlamsal bağların kurulmasını sağlamaktadır (Oraliş ve Ozil, 1992).

- Hava birden bire bozmuş, daha doğrusu poyraza çevirmiş̧i. Hâlbuki lodos akşamları ne güzeldi. Gece bozsaydı keşke hava. Bu İstanbul'un üstü altı, kırmızı, portakal gibi bulutlarla dolar, lodos başka türlü bir gök, başka türlü insanlar peyda ederdi. Hâlbuki poyrazla beraber, her zamanki soğuk bulutlar, soğuk insanlar, denizde içine girilemeyecek bir hâl. Hâlbuki lodosla kıșın bile denizde yıkanmak mümkün. (S. F. Abasıanık, Kestaneci Dostum)

Yukarıdaki paragrafta altı çizili sözcükler anlamsal olarak birbiriyle ilişkili sözcüklerdir ve paragrafta aynı kavram alanından sözcük kullanımı yoluyla sözcük bağdaşıklığı sağlanmıştır. $\mathrm{Bu}$ anlamsal ortaklıkları nedeniyle tümceler arasında bağlantı kurulmasına ve metnin tutarlılığına hizmet etmekte, okurun anlamsal bağlar kurmasına yardımcı olmaktadırlar. 


\section{Türkçenin Yabancı Dil Olarak Öğretilmesi Sürecinde Yazma Becerisi ve Bağdaşıklığın Önemi}

Dil öğretimi ya iletişimsel olaylara doğrudan katılım ya da bir metni doğrudan kullanma sonucu hedef dili öğrenme yeteneği ve bilgisidir. (Common European Framework, 2000, s. 123; Akt. Dilidüzgün, 2015, s. 17). Dil öğretimi sürecinde en temelde bireylerin hedef dili kullanarak iletişim kurmaları, hedef dilde okuduklarını ve dinlediklerini anlamaları amaçlanmaktadır. Dolayısıyla bu süreçte dil kurallarının öğretilmesinin yanı sıra dil becerilerinin geliştirilmesi ve dilin bir iletişim aracı olarak kullanılması önem taşımaktadır.

Öğrenilen dilde iletişim kurmak amacıyla kullanılan dil becerilerden biri yazmadır. Yazma becerisi Türkçe eğitiminde olduğu gibi Türkçenin yabancı dil olarak öğretiminde de öğrencilerin zorlandıkları bir dil becerisidir. Nitekim yabancı dil olarak Türkçenin öğretimi sürecinde öğrencilerin temel dil becerilerinden en çok yazma becerisinde zorlandıkları bazı araştırmalarla ortaya konmuştur (Açık, 2008; Biçer, Çoban ve Bakır, 2014; Kara, 2010; Maden ve İşcan, 2011).

Yazma, sadece duygu, düşünce, hayal ve izlenimlerin kâğıda aktarıldığı bir eylem değildir. Yazı oluşturma süreci son derece karmaşık bir süreçten oluşmaktadır (Witte and Faigley, 1981, s. 202; Akt. Göçer, 2011, s. 73). Yazma; fikirleri, hecelemeyi, el yazısını, noktalamayı içeren karmaşık bir süreçtir. Öğrenciler yazarken bu kadar çok amac1 gerçekleştirmekte güçlük çekmektedirler (Hannel, 2008).

Yazmada bir düşünme, fikir üretme, düzenleme ve ifade etme gibi eylemler vardır. $\mathrm{Bu}$ nedenle geliştirilmesi zor ve zaman alıcıdır. Aksan'a (2000) göre yazı dilinin konuşma diline göre daha kurallı olması bu zorluğu bir kat daha artırmaktadır.

"Konuşma ve yazma yoluyla anlatımın beynimizdeki oluşumu daha farklı ve karmaşıktır. Konuşma ve yazmanın bir de bellekte bilginin toplanması, düzenlenmesi gibi, sanki dil edinimi ile hiç ilgisiz gibi görünen yerlerle ilişkisi ortaya çıkmaktadır. Tanınan ve algılanan bilginin beyinde eksiksiz tutulması, tutulan bilginin anlaşılır bir biçimde beyinde sınıflandırılması, sınıflandırılan bilginin birbiri ile ilişkilendirilmesi gerekmektedir. Yalnızca ilişkilendirmek de yeterli olmamaktadır. Çünkü bilginin hızlı ve düzenli olarak beyinden elimize yazmak için akması gerekmektedir." (Yalçın, 2002, s. 25). Yazma yoluyla bir ürün ortaya çıkmal1, oluşturulan bu ürün belli bir bütünlük arz etmelidir. Bu bütün metindir ve metin kendisini oluşturan cümlelerin rastgele dizilmesiyle değil anlamlı şekilde bir araya gelmesiyle oluşmaktadır. Dil öğretiminde bireyin metin oluşturabilme düzeyine gelmesi o dili öğrenme sürecinde önemli bir gelişim gösterdiğinin ölçütüdür. Nitekim cümleleri anlamlı ve mantıklı bir bütün oluşturacak şekilde yazma, dil öğretiminde ulaşılması hedeflenen en önemli aşamalardandır. Bağdaşıklık metnin bütünlüğünü dilbilgisine ve söz varlığına bağlı olarak yansıtması nedeniyle metnin cümleler tarafindan gerçekleştirilmesinde temel niteliktir. Dolayısıyla bağdaşıklık ve bağdaşıklığı sağlayan unsurlar metin oluşturma sürecini ve yazma becerisinin niteliğini etkilediği için özel olarak yazma eğitiminde genel olarak da bir dilin öğretilmesi sürecinde oldukça önemlidir.

Yazma becerisi konusunda ustalaşmış bireyler, bağdaşıklık ilişkilerini her düzeyde kurabilmekte, birbirinden bağımsız dil birimlerini (ek, kelime, kelime grubu, cümle, paragraf) art arda, yan yana ve birbirine bağımlı yani birlikte değerlendirilebilir hâle getirebilmektedirler. Böylelikle metin, bir bütün olarak okuyucu tarafından kesintisiz biçimde ve bir çizgi doğrultusunda kolaylıkla algılanabilmektedir (Can, 2014, s. 206). Bağdaşıklık, yazma kalitesi açısından önemli bir özelliktir. Bu açıdan bağdaşıklık araçlarının türü ve ortaya çıkış sıklı̆̆ı, öğrencilerin orijinallik hakkındaki yeteneğini yansıtmakta ve yazdıkları metnin biçimsel ve organizasyonel özelliklerini etkilemektedir (Witte ve Faigley, 1981, s. 202; Akt. Karadeniz, 2015, s. 14). Dil öğretiminde yazılı anlatım çalışmaları yaparken metinde anlamsal bütünlüğe aracılık eden bağdaşıklık araçlarının bir bütün olarak öğretilmesi, öğrencilerin yazarken tutarlılığı sağlayan ögelere ilişkin bilişsel bir farkındalık kazanmalarını sağlayacaktır (Karatay, 2010). Bu bağlamda yabancı dil olarak Türkçenin öğretilmesi sürecinde de yazma becerisini geliştirirken dil öğrenenleri anlamlı ve bütünlük arz eden metin yazmaya yönlendirmenin büyük bir önemi vardır. 
Yazma eğitiminde Beaugrande ve Dressler'in (1981) de ifade ettiği gibi metin yapısındaki dil bilgisine dayalı ilişkileri metin oluşumunun temel gerekliliği olarak kabul ederek, bağdaşıklığı metin oluşturmanın ilk şartı olarak değerlendirmek ve öğrencilerin yazdıkları metinlerde bağdaşıklığa dayalı ilişkilerin niteliğini geliştirmek gerekmektedir. Dolayısıyla Türkçeyi yabancı dil olarak öğrenen öğrencilerin yazdıkları metinlerin metindilbilimsel açıdan çözümlenmesiyle elde edilen verilerin dil öğretimi ve yazma eğitiminin başarıya ulaşmasında katkı sağlayacağı düşünülmektedir. Bu gereklilik ve önemden yola çıkarak yapılan araştırmanın amacı Türkçeyi yabancı dil olarak öğrenen B1 düzeyindeki öğrencilerin yazdıkları öyküleyici metinlerin bağdaşıklık açısından nasıl bir görünüm sergilediğini tespit etmektir.

$\mathrm{Bu}$ amaç doğrultusunda şu sorulara yanıt aranmıştır:

- Türkçeyi yabancı dil olarak öğrenen B1 düzeyindeki öğrencilerin yazdıkları öyküleyici metinler dil bilgisi bağdaşıklığı açısından nasıl bir nitelik taşımaktadır?

- Türkçeyi yabancı dil olarak öğrenen B1 düzeyindeki öğrencilerin yazdıkları öyküleyici metinler sözcük bağdaşıklığı açısından nasıl bir nitelik taşımaktadır?

\section{Yöntem}

$\mathrm{Bu}$ araştırma durum çalışması olarak desenlenmiş, çalışmada veri toplama yöntemi olarak doküman incelemesi yöntemi kullanılmıştır. Doküman incelemesi, araştırılması hedeflenen olgu ve olaylar hakkında bilgi içeren yazılı materyallerin analizini kapsamaktadır ve dokümanlar nitel araştırmalarda etkili bir şekilde kullanılması gereken önemli bilgi kaynaklanıdır (Yıldırım ve Şimşek, 2005, s. 187-188). Araştırma kapsamında yabancı dil olarak Türkçe öğrenen öğrencilerin yazdıkları öyküleyici metinler incelenecek yazılı materyalleri oluşturmuştur.

\section{Çalışma grubu}

Araştırma kapsamında amaçlı örnekleme yöntemlerinden ölçüt örnekleme yöntemi kullanılmıştır. Ölçüt olarak B1 düzeyi belirlenmiş, verilerin B1 düzeyindeki öğrencilerden toplanmasına karar verilmiş ve çalışma grubunu B1 düzeyindeki 60 öğrenci oluşturmuştur. B1 düzeyinin ölçüt olarak belirlenmesinin çeşitli nedenleri vardır:

Avrupa Ortak Dil Kriterlerinin belirlediği 6 dil düzeyi A1, A2, B1, B2, C1 ve C2'dir. Bu dil düzeylerinden B1 düzeyinin yazılı anlatıma yönelik yetkinlik açıklaması şöyledir: "Uzun tasvirler yapabilir, geçmiş deneyimlerinden bahsedebilir, gelecekle ilgili projelerini anlatabilir, çevresindeki hayvanları ve nesneleri betimleyebilir" (Pillieux, 2005; Akt. Ada ve Şahenk, 2010, s. 73). Ayrıca Avrupa Dil Portfolyosunda yer alan Kendini Değerlendirme tablosunda B1 düzeyindeki öğrencilerin yazma becerisi açısından yapabilecekleri şöyle belirtilmiştir: "Bildik ya da ilgi alanına giren konularla bağlantıl basit bir metin yazabilirim. Deneyim ve izlenimlerimi betimleyen kişisel mektuplar yazabilirim" (Council of Europa, 2007; Akt. Akt. Ada ve Şahenk, 2010, s. 78).

$\mathrm{Bu}$ yeterlilik ölçütlerinden yola çıkarak B1 düzeyindeki öğrencilerin öyküleyici bir metin yazabilmek için uygun olduğu düşünülmüş, Çukurova Üniversitesi Türkçe Öğretimi Uygulama ve Araştırma Merkezi ile Adana Bilim ve Teknoloji Üniversitesi Türkçe Öğretimi Uygulama ve Araştırma Merkezinden B1 yeterlilik düzeyinde olan öğrencilerden gönüllük esasına dayalı olarak seçilen 60 öğrenci çalışma grubunu oluşturmuştur. Çalışma grubunu oluşturan öğrencilerin kişisel bilgileri Tablo 1'de sunulmuştur:

Tablo 1

Çalışma Grubunu Oluşturan Öğrencilerin Kişisel Bilgileri

\begin{tabular}{cccc}
\hline & & $\mathrm{f}$ & $\%$ \\
\hline \multirow{2}{*}{ Cinsiyet } & Erkek & 32 & 53,3 \\
& Kadın & 28 & 46,7 \\
\hline \multirow{2}{*}{ Yaş } & $19-24$ & 32 & 53,3 \\
Aralığ & $25-30$ & 25 & 41,7 \\
& $31-34$ & 3 & 5 \\
\hline
\end{tabular}




\begin{tabular}{|c|c|c|c|}
\hline \multirow{18}{*}{ Ülke } & Suriye & 34 & 56,6 \\
\hline & Irak & 6 & 10 \\
\hline & Benin & 2 & 3,3 \\
\hline & İran & 2 & 3,3 \\
\hline & Kazakistan & 2 & 3,3 \\
\hline & Orta Afrika Cumhuriyeti & 2 & 3,3 \\
\hline & Bangladeş & 1 & 1,7 \\
\hline & Belarus & 1 & 1,7 \\
\hline & Botsvana Cumhuriyeti & 1 & 1,7 \\
\hline & Cezayir & 1 & 1,7 \\
\hline & Cibuti & 1 & 1,7 \\
\hline & Çin & 1 & 1,7 \\
\hline & Filipinler & 1 & 1,7 \\
\hline & Komorlar & 1 & 1,7 \\
\hline & Kongo Demokratik Cumhuriyeti & 1 & 1,7 \\
\hline & Kurgizistan & 1 & 1,7 \\
\hline & Mali & 1 & 1,7 \\
\hline & Yemen & 1 & 1,7 \\
\hline \multirow{14}{*}{ Ana Dili } & Arapça & 43 & 71,6 \\
\hline & Fransizca & 4 & 6,6 \\
\hline & Farsça & 2 & 3,3 \\
\hline & Azerbaycan Türkçesi & 1 & 1,7 \\
\hline & Bengali & 1 & 1,7 \\
\hline & Filipino & 1 & 1,7 \\
\hline & Kazakça & 1 & 1,7 \\
\hline & Komorca & 1 & 1,7 \\
\hline & Lingala & 1 & 1,7 \\
\hline & Özbekçe & 1 & 1,7 \\
\hline & Rusça & 1 & 1,7 \\
\hline & Sango & 1 & 1,7 \\
\hline & Setsvana & 1 & 1,7 \\
\hline & Uygurca & 1 & 1,7 \\
\hline Hangi & Yazma & 38 & 63,3 \\
\hline Dil & Dinleme & 15 & 25 \\
\hline Becerisi & Konuşma & 4 & 6,7 \\
\hline Daha Zor & Okuma & 3 & 5 \\
\hline
\end{tabular}

Tablo 1'de görüldüğü gibi çalışma grubunda yer alan öğrencilerin $32(\% 53,3)$ 'si erkek, 28 (\%46,7)'i kadındır. Tabloda yer aldığ 1 biçimde yaş aralığ 1 bakımından 19-30 yaş arası, çalışma grubunun \%95'ini oluşturmaktadır. Çalışma grubundaki 3 (\%5) öğrenci ise 30-34 yaş aralığındadır. Çalışma grubunu oluşturan öğrencilere ülkeleri sorulduğunda, 34 (\%56) öğrencinin Suriyeli, 6 (\%10) öğrencinin de Iraklı olduğu; ikişer öğrencinin Benin, İran, Kazakistan, Orta Afrika Cumhuriyeti, birer öğrencinin de Bangladeş, Belarus, Botsvana Cumhuriyeti, Cezayir, Cibuti, Çin, Filipinler, Komorlar, Kongo Demokratik Cumhuriyeti, Kırgizistan, Mali ve Yemen menşeli olduğu görülmüştür. Öğrencilere ana dilleri soruduğunda $43(\% 71,6)$ öğrenci Arapça yanıtını vermiştir. Çalışma grubundaki 4 öğrenci Fransızca, 2 öğrenci Farsça, birer öğrenci de Azerbaycan Türkçesi, Bengali, Filipino, Kazakça, Komorca, Lingala, Özbekçe, Rusça, Sango, Setsvana, Uygurca yanıtını vermiştir.

Çalışma grubunu oluşturan öğrencilere Türkçeyi öğrenirken en çok zorlandıkları dil becerisi sorulduğunda $38(\% 63,3)$ öğrenci yazma, $15(\% 25)$ öğrenci dinleme, 4 (\%6,7) öğrenci konuşma, 3 (\%5) öğrenci de okuma yanıtını vermiştir. Çalışma grubunu oluşturan öğrencilerin zorlandıkları dil becerisi olarak yazmayı belirtmeleri alan yazınıyla örtüşmektedir. Ana dili 
olarak Türkçe öğrenen bireylerin en çok yazma becerisinde zorlandıkları farklı araştırmacılar tarafından ortaya konmuştur (Açık, 2008; Kara, 2010; Maden ve İşcan, 2011; Biçer, Çoban ve Bakır, 2014). Yabancı dil olarak Türkçenin öğreniminde -ana dili olarak Türkçe öğrenimine benzer şekilde- en çok yazmaya yönelik kaygıların olduğu görülmektedir (Maden, Dinçel ve Maden, 2015).

\section{Verilerin toplanması}

Yabancı dil olarak Türkçe öğrenen B1 düzeyindeki öğrencilerin yazdıkları öyküleyici metinlerin bağdaşıklık açısından nasıl bir görünüm sergilediğini saptamak amacıyla yapılan araştırma kapsamında veri toplayabilmek için öğrencilere öykü tamamlama etkinliği yaptırılmıştır. B1 düzeyindeki öğrenimlerini tamamlamış olan öğrencilerin aldıklanı Türkçe öğretimi göz önünde bulundurularak deneyim ve izlenimlerini yansitabilecekleri, betimlemeler yapabilecekleri bir olay metni yazabilecekleri varsayılmıştır. Bu varsayımdan hareketle öncelikle A1, A2 ve B1 düzeyinde hazırlanmış ders kitaplarında bulunan metinler ve yazma becerisini geliştirmeye yönelik etkinlikler incelenmiş, bu doğrultuda çeşitli yazma konuları belirlenmiştir. Daha sonra bu konular uzman görüşüne sunulmuş, Türkçe eğitimi ve yabancı dil olarak Türkçe öğretimi alanında görev yapan uzman kişilerden görüşleri alınmıştır. $\mathrm{Bu}$ doğrultuda öğrencilerden başlatıcı olayın verildiği bir öyküyü tamamlayarak en az 550-700 (Sözcük sayıs1, yabancı dil olarak Türkçe ögretimi alanında yazma çalışmaları yaptıran uzmanların önerileri doğrultusunda, bir olay yazısında ifade ve metin bütünlügünü sağlayabilecek asgari düzey olarak belirlenmiştir.) sözcükten oluşan bir öykü yazmaları istenmiştir. Uygulama 2016 yılında yapılmış, öğrencilere yazmaları için 50 dakika süre verilmiştir.

\section{Verilerin analiz edilmesi}

Öğrenciler tarafından yazılan öyküleyici metinlerin bağdaşıklık açısından değerlendirilmesinde bağdaşıklığı sağlayan ögeler ölçüt olarak alınmış ve öğrencilerin yazdıkları metinlerde söz konusu bağdaşıklık ögelerini kullanma sıklıkları belirlenmeye çalışılmıştır. Bu amaçla içerik analizi yapılmış, her bir öğrenci tarafından yazılan metin iki araştırmacı tarafından ayrı ayrı değerlendirilmiştir. Öyküleyici metinlerin bağdaşıklık özelliklerini metindilbilimsel açıdan değerlendirebilmek için bağdaşıklığa ilişkin yapılan kuramsal açıklamalar bağlamında (Beaugrande ve Dressier, 1981; Halliday ve Hasan, 1976; Uzun, 1995) bir değerlendirme formu oluşturulmuş ve her bir öğrencinin yazdığı metin bağdaşıklık ögelerine yer verme niteliği bakımından değerlendirilmiştir. Bu değerlendirme formunda bağdaşıklık ögeleri iki ana bölüme ayrılmış, bağdaşıklık, dil bilgisi bağdaşıklığı ve sözcük bağdaşıklığı başlıkları altında ele alınmıştır. Öğrenci metinleri dil bilgisi bağdaşıklığı açısından gönderim, değişstirim, bağlama ögeleri ve eksiltiye yer verme açısından incelenmiş, sözcük bağdaşıklığına yönelik olarak tekrar (kelimenin aynen tekrar edilmesi, eş veya yakın anlamlı sözcük kullanımı, üstterim-altanlamlılık içeren sözcük kullanımı, aynı kökten türemiş farklı sözcük kullanımı) ve aynı kavram alanından sözcük kullanımı açısından değerlendirilmiştir. Türkçeyi yabancı dil olarak öğrenen çalışma grubundaki her bir öğrencinin yazdıkları öyküleyici metinlerde bu ögeleri ne siklıkla kullandıkları tespit edilmeye çalışmıştır. Öğrenci metinlerinde her bir bağdaşıklık ögesine yönelik örnek kullanımlara metinlerden doğrudan alıntılar yapılarak yer verilmiştir.

\section{Geçerlik ve güvenirlik}

Bir metnin bağdaşıklık açısından sahip olması gereken niteliklerin saptanması amacıyla öncelikle ilgili alan yazını taranmış, bağdaşıklık ögelerine ilişkin sınıflandırmalar incelenmiş ve öğrenci metinlerinde aranacak ögeleri içeren bir değerlendirme formu oluşturulmuştur. Bu form, araştırmacıların değerlendirmelerini yani söz konusu bağdaşıklık ögelerinin kullanılma sıklığını yazdıkları bir form olup ilgili alan yazınındaki kuramsal bilgilere dayanmaktadır. Bu bağlamda elde edilen bulguların daha önce oluşturulan kavramsal çerçeveyle uyumlu olup olmadığı, bu çerçevenin veri toplamada rehber olup olmadığı (Yıldırım ve Şimşek, 2005) sorularına yanıt verecek nitelikte bir yol izlenmiş, bu sürecin iç ve dış geçerliğe katkı sağlayacağı umulmuştur. 
Bununla birlikte çalışma grubu bir kurumdan seçilmemiş, iki farklı kurumdan seçilerek çeşitlendirilmiştir.

Nitel araştırmalarda güvenirliği sağlamak için verilerin analiz edilmesi sürecinde başka bir araştırmacının da görüşünü almak oldukça önemlidir. Söz konusu olan yazma becerisinin değerlendirilmesiyse bu daha da önem taşıyan bir duruma dönüşmektedir. Bu araştırma kapsamında güvenirliği sağlamak için her bir öğrenci metni iki araştırmacı tarafından da ayrı ayrı değerlendirilmiş, öğrencilerin yazdıkları öyküleyici metinlerde hangi bağdaşıklık ögelerine, ne sıklıkta yer verdikleri her iki araştırmacı tarafından incelenmiştir. $\mathrm{Bu}$ incelemede araştırmacılar hem değerlendirme formunu kullanmış, hem de öğrenci metinlerinden bağdaşıklık ögelerinin kullanımlarına yönelik örnek cümleleri not almışlardır. Daha sonra iki araştırmacının yaptıkları değerlendirmeler karşılaştırılmış, araştırmacıların yaptıkları değerlendirmelerin \%98 uyuşum gösterdiği gözlemlenmiştir.

\section{Bulgular ve Tartışma}

$\mathrm{Bu}$ çalışmada, öğrencilerin yazdıkları metinler bağdaşıklık ögeleri bakımından dil bilgisi bağdaşıklı̆̆ı ve sözcük bağdaşıklığı olmak üzere iki ana başlıkta değerlendirilmiştir. Dil bilgisi bağdaşıklığı altında gönderim, değiştirim, eksilti, bağlama ögeleri; sözcük bağdaşıklığı başlığı altında ise tekrar (kelimenin aynen tekrar edilmesi, eş veya yakın anlamlı sözcük kullanımı, üstterim-altanlamlılık içeren sözcük kullanımı, aynı kökten türemiş farklı sözcük kullanımı) ile aynı kavram alanına giren sözcükler ele alınmıştır.

Tablo 2

Dil Bilgisi Bağdaşıklığı (Gönderim)

\begin{tabular}{lcc}
\hline & $\mathrm{f}$ & $\%$ \\
\hline Kişi Zamiri & 510 & 64,31 \\
Dönüşlülük Zamiri & 37 & 4,67 \\
İssaret Zamiri & 51 & 6,43 \\
İşaret Sıfatı & 195 & 24,59 \\
\hline \multicolumn{1}{c}{ TOPLAM } & & 100 \\
\hline
\end{tabular}

Tablo 2'de görüldüğü üzere yabanc1 dil olarak Türkçe öğrenen öğrencilerin yazmış oldukları öykülerde, dil bilgisi bağdaşıklığı ögesi olarak gönderim birimlerinden en çok kişi zamirleri kullanılmıştır: \%64,31. Sıklı̆g 1 en düşük olan gönderim birimi ise dönüşlülük zamiridir: \%4,67. Öğrencilerin yazdıkları öykülerde tespit edilen tanıklarda kişi zamirleri, art gönderim ögesi olarak kullanılmıştır:

"Ö.42 Öğretmen bize (sınıftaki arkadaşları ile birlikte) kayıtları verdi."

"Ö.46 İki dakika düşündükten sonra en yakın arkadașıma telefon etmeyi çalıştım. Ona geçtiğim durumu anlattım."

"Ö.49 Kütüphane içerisine sihirbaza benzeyen bir kişi girdi. Onun bacakları 0,5 metre yüksekteydi."

"Ö.51 Arkadașım kütüphaneye geldi ve sınavımız soruları yanına getirdi. Ben ona "Nereden bunlar aldı çok problem olacak biliyor musun?" diye sordum."

"Ö.52 Birkaç saat çalışıyor sonra sağ tarafımdaki rafta bulunan şiir kitaplarına dadanıyorum. Onları okudukça derse dönmek çok zor geliyor."

Dönüşlülük zamiri $(\% 4,67)$, öğrenci öykülerinde en az kullanılan gönderim ögesidir. Dönüşlülük zamiri, öğrenci öykülerinde art gönderim unsuru olarak kullanılmıştır. Öykülerde, kendisinden önceki bir unsuru pekiş̧irme yoluyla karşıladığı görülmektedir:

"Ö.13 Her eve geldiğimde beni köpek gibi kapıda karşılar kendini sevdirirdi."

"Ö.18 Kendime sordum [...] kendim ile konuştum." 


\section{"Ö.21 Kendi aralarında muhabbet ediyorlardı."}

Yabancı dil olarak Türkçe öğrenen öğrencilerin yazdıkları öykülerde, işaret zamirlerinin gönderim amacıyla kullanım oranının \% 6,43 olduğu saptanmıştır. Bu tür zamirler, art ve ön gönderim unsurları olarak kullanılmışlardır:

"Ö.41 Dışarıya gitti ve evine döndü orada ödevlerini yapmaya başladı."

"Ö.42 [...] arkadaşlarım diğer kitaplara çalışıyorlara rağmen ben onlara bakmıyorum."

"Ö.49 Kütüphane içerisine sihirbaza benzeyen bir kişi girdi [...] $\mathrm{O}$ bana neden burda olduğumu ve neden [...]"

"Ö.54 Bundan sonra sertifika aldı ama bu onun için yeter değil."

"Ö.40 Çünkü bu bizim sinav olacaktı."”

Öğrenci öykülerinde işaret sıfatlarının gönderim amacıyla kullanım oranı \%24,59'dur. Öykülerde işaret sıfatlarının art ve ön gönderim unsuru olarak kullanımları saptanmıştır:

"Ö.1 Adamlarla göz göze geldik. Bu iki adamı gördükten sonra..."

"Ö.47 Ailem her zaman para gönderiyor ama o paralar benim rahat okumam için yetmiyor."

"Ö.24 Sınavın ertelenmesini söyledi. Biz bu habere çok endişelendik."

"Ö.45 Ama bu adam yani ruh "korkma" söyledi."

"Ö.23 İçeri o kișiler girdi. Biri erkek biri bayan."

Öğrenci öykülerinde tespit edilen iki zamir türü daha mevcuttur. Bunlar, soru zamiri ve belgisiz zamirdir. Öğrenci öykülerinde soru zamirinin ön gönderim, belgisiz zamirin ise art gönderim ögesi olarak kullanıldığı saptanmıştır:

"Ö.50 Benim telefonum tekrar çaldı. Kim beni aradı bilmiyordum [...] sonra telefonum tekrar çaldı ve babam beni aradı."

"Ö.5 [...] babam, annem, kardeșlerim hepsi gittiler."

"Ö.9 Geri önemli konulara baktım. Hepsini birer birer kendimi anlattım."

Araştırma kapsamında öğrenci öykülerinden elde edilen bulgular, ana dili olarak Türkçe öğretimine yönelik yapılan çalışmalarla örtüşür durumdadır. Seçkin, Arslan ve Ergenç (2014, s. 346), lise 1 ve 3 ile üniversite 1 ve 3. sınıf öğrencilerine öykü tamamlatmışlardır. Bu çalışmada elde edilen bulgulara göre öğrencilerin en çok kullandıkları gönderim ögesi, sıklıklarına göre şöyle sıralanmaktadır: Kişi zamiri (1004), işaret sıfatı (408), işaret zamiri (161) ve dönüşlülük zamiri (70). Yıldırım (2016, s.76), B1 düzeyinde Türkçe öğrenen yabancıların yazılı anlatımlarında, gönderim ögesi olarak en sık kişi zamirlerinin (\%45) geçtiğini belirtmiştir. İşaret zamirleri $\% 23$, işaret sıfatları $\% 13$, dönüşlülük zamiri $\% 3$ oranında kullanılmıştır.

Dil öğrenen bireyin varlıkları adlandırmada ve aynı adı metin içinde tekrardan kaçınmada kişi zamirlerini kullanması beklendik bir durumdur. Türkçede teklik ve çokluk üç kişi kategorisini de gösteren ve sınırlı sayıda olan bu birimlerin kolayca öğrenilmesi, Türkçeyi yabancı dil olarak öğrenen bireyin ifade çabasını kolaylaştırmaktadır. Bu çalışmada tespit edildiği gibi kişi zamirlerinin diğer gönderim ögelerinden daha sık kullanılması, ayrıca diğer bağdaşıklık ögeleri arasında da \%20,73'lük bir kullanım sıklı̆̆ına sahip olması -yazdıkları metnin öykü türünde olduğu gerçeğini göz ard1 etmemek gerekir- bu durumun bir tezahürü olmalıdır. 
Tablo 3

Dil Bilgisi Bağdaşıklığı (Değiștirim)

\begin{tabular}{ccc}
\hline & $\mathrm{f}$ & $\%$ \\
\hline İsme Dayalı & 6 & 18,75 \\
Fiile Dayalı & 4 & 12,5 \\
Cümleye Dayalı & 22 & 68,75 \\
\hline TOPLAM & & 100 \\
\hline
\end{tabular}

Yabancı dil olarak Türkçe öğrenen öğrencilerin yazdıkları öykülerdeki dil bilgisi bağdaşıklığı ögeleri içinde en az kullanılanı değiştirimdir: \%1,43. Değiştirim kategorisindeki ögelerin kullanım sıklığı ise şöyledir: Cümleye dayalı değiştirim \%68,75, isme dayalı değiştirim $\% 18,75$, fiile dayalı değisstirim \%12,5. Bu kullanım oranları gerek ana dili gerekse yabancı dil olarak Türkçe öğrenen bireyler üzerine yapılan farklı çalışmalarla örtüşmektedir. Yıldırım (2016, s. 77), B1 düzeyinde Türkçe öğrenen yabancıların yazdıkları metinlerde değiştirim ögelerinin kullanım sıklıklarını şöyle belirtmiştir: cümleye dayalı değiştirim \% 78,5, isme dayalı değiştirim \%14,2, fiile dayalı değiştirim \%7,14. Seçkin ve diğerlerinin (2014, s. 340-353) 11. sınıflarla yaptıkları çalışmalarında tespit ettikleri 3 değiştirim ögesinden ikisi $(\% 66,7)$ cümleye dayalı değiştirim, biri $(\% 33,3)$ isme dayalı değiştirimdir. Bu çalışmada yaş gurubu ve öğretim kademesi değiştikçe değiştirim ögesi kullanım oranlarının de değiştiği tespit edilmiştir. Üniversite 1. sınıf öğrencilerinin metinlerindeki 8 değiştirim ögesinden dördü (\%50) isme dayalı değiştirim, dördü (\%50) de fiile dayalı değiş̧tirimdir. Bu gurupta cümleye dayalı değiştirim örneği saptanmamıștır. Üniversite 3. sınıf öğrencilerinin metinlerinde ise yalnızca fiile dayalı değiştirim saptanmıştır. Can (2012, s. 252), 9. ve 10. sınıflarla gerçekleştirdiği çalışmasında en s1k kullanılan değiştirim ögesi olarak cümleye dayalı değiştirimi $(\% 72,26)$ tespit etmiştir. $\mathrm{Bu}$ çalışmadaki öğrenci metinlerinde fiile dayal değiştirim \%14,59, isme dayalı değiştirim ise $\% 13,13$ oranında kullanılmıştır.

Tablo 3'te görüldüğ̈̈ gibi değiştirim kategorisinde en sık kullanılan, cümleye dayalı değiştirimdir: \%68,75. Öğrenci öykülerinde böyle ve şöyle kelimeleriyle yapılan değiştirim, hem kendisinden önce hem de kendisinden sonraki cümleye yönelik olarak kullanılmıştır.

"Ö.7 Gözlerimin içine bakarak șöyle dedi. Üç dilek hakkın var evlat."

"Ö.9 Herkes düşündüklerini aklındaki kalan sorularını anlattı. Böyle zamanım geçti."

"Ö.10 Türkçe hem kolay hem zor bir dil. Böyle düşünüyorum."

"Ö.29 Bu konuda şöyle düşünüyorum. Bu konuyu ele alırken farklı pencerelerden bakmaliyız."

Tablo 3’te görüldüğüü üzere isme dayalı değiştirimin kullanım sıklı̆̆ \%18,75'tir. Böyle, şöyle ve öyle kelimeleriyle yapılan değiştirimler, kendisinden önceki isme yöneliktir.

“Ö.1 Ahmet 2010da Musul Üniversitesi tıp bölümünden mezun oldu. Ayşe ise aynı üniversiteden..."

"Ö.11 Samiye yardımından dolayı ona teşekkür ettim. [...] Böyle bir arkadașım olduğu için çok mutluyum."

"Ö.48 O anda kendi hikayemi anlatmaya başladım. Sizce bu seviyeye kadar nasıl geldim ben çalışmadan? Beni böyle görünce tembel ve sorumsuz bir insan olduğumu zannediyorum ancak öyle değil."

Öğrenci öykülerinde, değiştirim kategorisine yönelik kullanımlar içinde sıklığı en düşük olan fiile dayalı değiştirimdir: \%12,5.

"Ö.7 Babam da böyle yapacağımı anlamışçasına."

"Ö.11 Benim böyle sustuğumu görünce bana düşünceli halimin sebebini sordu." 
"Ö.24 Kütüphane bomboş "Kim böyle yapıyormuş acaba burada cin var." diye düşünüyorum."

Öğrencilerin öykülerinde, dil bilgisi bağdaşıklığı kategorilerinde sıklığı en düşük olan değiştirimdir. Bu durum, konuyla ilgili diğer çalışmalarla örtüşmektedir. Can (2012, s. 249), ortaöğretim 9 ve 10. sınıf öğrencilerinin yazdıkları metinlerde en düşük kullanım oranına sahip bağdaşıklık birimi olarak değiştirimi tespit etmiştir: \%0,46. Keklik ve Y1lmaz (2013, s. 139157), 11. sınıf öğrencilerinin öyküleyici metinlerinde en az kullanılan bağdaşıklık ögesinin değiştirim olduğunu saptamıştır: \%1,69. Karabağ ve İşsever (1995, s. 221-235), 48-60 ay arasındaki çocuklarla yaptıkları çalışmalarında değiştirim ögeleri saptamamışlardır. Ana dili olarak Türkçe öğretiminin yanı sıra yabancı dil olarak Türkçe öğretimine yönelik çalışmalarda da benzer sonuçlara ulaşıldığı görülmektedir. Yıldırım (2016, s. 77), B1 düzeyinde Türkçe öğrenen yabancıların yazdıkları metinlerde değiştirim ögelerinin yok denecek kadar az olduğunu belirtmiştir. Yıldırım'ın çalışmasında değiştirim ögelerinin katılımcı başına düşen ortalamas $1 \% 0,14$ 'tür. Türkçe dışındaki dillerde bağdaşıklık ögelerinin incelendiği çalışmalarda da benzer sonuçlar görülmektedir. Ürdün'de 12. sınıf öğrencilerinin İngilizce yazdıkları metinler üzerine çalışan Ramadan (2003), bağdaşıklık ögeleri içinde değiştirimi tespit edememiştir.

Tablo 4

Dil Bilgisi Bağdaşıklığı (Eksilti)

\begin{tabular}{lcc}
\hline & $\mathrm{f}$ & $\%$ \\
\hline Özne & 346 & 59,87 \\
Tümleç & 59 & 10,21 \\
Nesne & 32 & 5,53 \\
Tamlayan & 141 & 24,39 \\
\hline \multicolumn{2}{c}{ TOPLAM } & 100 \\
\hline
\end{tabular}

Öğrencilerin yazdıkları öykülerde, eksiltinin bağdaşıklık ögesi olarak kullanım oranı $\% 25,77$ 'dir. Tablo 4'te öğrencilerin öykülerinde en çok özne eksiltme $(\% 59,87)$ yoluyla tekrardan kaçınıldığı ve bu şekilde başka bir unsurla bağdaşıklığın sağlandığı görülmektedir. Türkçe cümlelerde işin faili ya da mefulü zaten yüklemde kategorik olarak belirtildiği için dil kullanırının özneyi her seferinde anması gerekmemektedir (Ergin, 2009, s. 399).

"Ö.18 (Ben) çalışma takip ettim. [...] (Ben) tamamen böyle yaptım."

"Ö.23 Biri erkek biri bayan. (Onlar) gözlerini kütüphanedeki diğer insanlar üzerinde gezdiriyorlardı."

Çalışma grubundaki öğrencilerin en az kullandıkları eksiltme türü nesne eksiltmedir: \%5,53. Nesne eksiltmelerinde, önceki cümlelerde belirtilen aynı ya da başka öge görevli birime atıf söz konusudur.

"Ö.18 Ders çalışmak istedim. [...] sonra (ders) çalışmak başladım."

"Ö.54 Orada ödevlerini yapmaya başladı. (Ödevleri) Bittikten sonra aklına iyi bir fikir geldi."

Belirtili isim tamlamalarında ya da iyelik gruplarında tamlayan ögenin daha önce anılmasından ötürü tekrarlanmaması durumu Türkçede sıkça görülen bir özelliktir. Özellikle iyelik gruplarında birinci öge olan iyelikli unsurun zaten kişi kategorisi gösteriyor olması bu sonucu doğurmaktadır. Öğrencilerin yazdıkları öykülerde her iki biçimi de kapsayacak şekilde tamlayanın eksiltildiği örneklerin kullanım oranı \%24,39'dur.

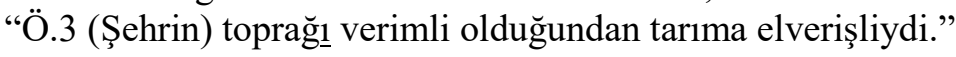


“Ö.8 Bu yüzden onu fazla sulamaz ve (onun) bakımını yapmaya pek istemezdim.” "Ö.50 Allahım bana yardım et."

Öğrencilerin yazdıkları öykülerde tümleç eksiltiminin oranı \%10,21'dir. Bu kategorideki eksiltmeler, kendisinden önce aynı ya da başka görevle belirtilen bir ögenin sonraki cümlede tümleç göreviyle işaretlenmemesi suretiyle gerçekleşmiş̧ir.

"Ö.18 (Evde) elektrik kesilmiş. [...]"

"Ö.44 Sınavlar kolayca oldu çünkü (sınavlarda) okuduğum dersler çıkardı."

"Ö.48 Sözümü bitirdikten sonra o kelebek (masada) yoktu."

"Ö.54 En son sinav gelmeden önce kendisi positive hissetti ve (sınava) girdikten sonra mutlu oldu ve iyi not aldı."

Bu kategoriler dışında Türkçede ortak bir yüklemle iki cümlenin bağlanması da bir anlatım özelliği olarak öğrenci öykülerinde saptanmıştır:

\section{“Ö.7 ... bazıları okumak ister bazıları ise uçmak (isterdi).”}

Yukarıdaki alıntı cümle, "Bazıları okumak, bazıları ise uçmak ister." biçiminde de kullanılabilir ve dolayısıyla bir devrikleme örneği olarak görülebilir: Ancak dil gerçekliği, ifade edilenin yeniden tasarlanmasından ziyade kullanılmış olan biçimin iletişimsel değeri olarak düşünüleceğinden bu tanık, eksilti örneği olarak ele alınmıştır.

$\mathrm{Bu}$ çalışmada eksilti kavramı, cümleyi oluşturan ögelerde ya da onun alt kategorisi olarak kelime gruplarında çeşitli birimlerin eksiltilmesi olarak ele alınmıştır. Alan yazını incelendiğinde, ana dili ya da yabancı dil olarak Türkçe öğretimi üzerine yapılan çalışmalarda genellikle öge ve ek eksiltme üzerinde durulduğu görülmektedir. Seçkin ve diğerleri (2014, s. 340-353), farklı kademelerdeki öğrencilerle yaptıkları çalışmalarında sınıf seviyesi ile eksilti kullanımının ters orantılı olduğu sonucuna varmışlardır. 9. sınıf öğrencilerinin yazdıkları metinlerdeki 173 eksiltili anlatıma karşılık üniversite 3. sınıf öğrencilerinin metinlerrinde 17 eksiltili anlatım tespit etmiş̧lerdir. 9. sınıf öğrencilerinin en sık kullandıkları eksiltili anlatım öge eksiltme iken üniversite 1 ve 3. sınıf öğrencilerininki ek eksiltme olarak saptanmıştır. B1 düzeyinde Türkçe öğrenen yabancıların yazdıkları metinler üzerine çalışan Yıldırım (2016, s. 77), öğrencilerin en çok ortak ögeleri düşürdüğünü, ek düşürme oranının ise çok daha az olduğunu tespit etmiştir. Araştırmacı, çalışmasında cümle düşürülmesine rastlamadığını belirtmiştir.

Tablo 5

Dil Bilgisi Bağdaşıklığı (Bağlama Ögeleri)

\begin{tabular}{lccc}
\hline & $\mathrm{f}$ & $\%$ \\
\hline Bağlaç & 554 & 65,95 \\
Edat & 286 & 34,05 \\
\hline \multicolumn{2}{c}{ TOPLAM } & 100 \\
\hline
\end{tabular}

Yabanc1 dil olarak Türkçe öğrenen öğrencilerin yazdıkları öykülerdeki dil bilgisi bağdaşıklığı ögeleri içinde en çok kullanılanı bağlama ögeleridir: \%37,45. Tablo 5'te görüldüğü gibi bağlama ögesi olarak en sık bağlaçlar kullanılmıştır: \%65,95. Başka bir ifadeyle bağlama ilgisine ait her üç tanıktan ikisi bağlaçla, biri ise edatların oluşturduğu kelime gruplarıyla sağlanmıştır. Bu çalışma kapsamında bağlaçların anlam ayırtları üzerinde durulmamış, genel bir özellik olarak bağlaçlar ve edatlı yapıların bağlama işlevli dil bilgisel bağdaşıklığı nasıl sağladığı, bunların anlamca uygun kullanılıp kullanılmadığı değerlendirilmiştir. Öte yandan öykülerde en çok sıralama (ve, ile) ilgisiyle kullanılan bağlaçlara yer verilmiştir: \%53,19. Yıldırım'ın (2016, s. 78) B1 düzetinde Türkçe öğrenen yabancı öğrencilerle yaptığ 
çalışmasında en çok sıralama bağlaçlarının $(\% 39,2)$ kullanıldığı, en az ise açıklama bildiren $(\% 3,4)$ ve koşul bildiren $(\% 3,5)$ bağlaçların kullanıldığı tespit edilmiştir. Seçkin ve diğerlerinin (2014, s. 340-353) çalışmalarında da bağlaç kategorinin unsurlarından sıralama bağlaçları 9. sinıflarda $\% 63,5,11$. sinıflarda $\% 44,2$, üniversite 1 . siniflarda $\% 70,1$, üniversite 3 . sinıflarda ise $\% 78,5$ 'lik oranla en çok kullanılan bağlaçlardır. Bağlaçların içinde en sık kullanılanın sıralama bağlaçları olduğunu gösteren bir başka çalışma Keklik ve Yılmaz (2013, s. 139-157)'a aittir. 11. sınıf öğrencileriyle yapılan bu çalışmada sıralama bağlaçlarının kullanım oranı \%50,52'dir. Ayaz'ın (2007, s. 38) çalışmasında da en çok sıralama bağlaçlarının $(\% 41,01)$ kullanıldığı görülmektedir.

$\mathrm{Bu}$ araştırma kapsamında, öğrencilerin yazdıkları öykülerde, Korkmaz'ın (2009, s. 1104) sınıflandırmasında yer alan seçme bağlaçları (veya), pekiştirme bağlaçları (bile, de, hem), cümle bağlayıcısı niteliğindeki bağlaçların (zıtlık, sebep, açıklama ilgileriyle) sıkça kullanıldığı saptanmıştır. Kullanım sıklığı en düşük olanlar ise pekiştirme bağlaçlarıdır: \%6,41.

"Ö.6 Nitekim çok yorgun oldum ne var ki aynı zamanda çok mutlu oldum. [...] Öğretmenim hem sabırlı hem iyi kalpli."

"Ö.7 Annemi hayal bile edemiyordu."

"Ö.10 Türkçe hem kolay hem zor bir dil."

"Ö.11 Ertesi gün sinava girdim ve çok iyi bir notla geçtim."

"Ö.28 Birisi inanılmaz bir şekilde gülerek "Sen şaka mı yapıyorsun?" diye sordu ama açıkladı ki bu şaka değil.”

"Ö.36 O o kadar mutluydu ki mutluluktan yerinde duramıordu."

"Ö.43 Neden bu yazıyor bilmem ama bir şey bundan öğrendim."

"Ö.45 Ne var ki bir adam sesini duymaya başladı."

“Ö.50 Çünkü telefonu almadım.”

Edatlar görevli biçimbirimler olarak Türkçe cümlelerde birimler arası bağı, çeşitli anlam ilgileri ile sağlarlar. Özellikle zamirlerin ardı sıra gelerek oluşturdukları kelime grupları, içinde bulunduğu birimin gönderimi ile diğer birim ya da birimleri benzerlik, eşitlik, sebep, miktar vd. anlam ilgileriyle bağlamaktadır. Tablo 5 'te görüldügü üzere öğrenci öykülerinde edatlar, bağlama ögesi olarak \%34,05 oranında kullanılmıştır. Öğrencilerin öykülerinde gibi, için, kadar, önce, sonra, ile, ait, üzere, göre, başka, birlikte, diye, rağmen, beri, dolayl, karşı edatlarının kullanımı saptanmıştır.

“Ö.1 Sonra üniversiteyi bitirmek için Musul'a geldiler."

"Ö.11 Samiye yardımından dolayı ona teşekkür ettim."

"Ö.13 Her eve geldiğimde beni köpek gibi kapıda karşılar kendini sevdirirdi."

"Ö.14 Hiç ders çalışmıyor ona göre ders çalışmak önemli değil."

"Ö.18 Kendim ile konuştum. [...] Sınav günü sınav için hazırlandım."

"Ö.20 Sabahtan akșama kadar çalıșıorum."

"Ö.33 Ben ondan niçin geldin ne işin var burda, benden ne istiyorsun diye sorular sordum."

"Ö.36 O o kadar mutluydu ki mutluluktan yerinde duramiyordu. [...] Sinavdan önce emindim."

“Ö.38 O yere vardığımızda o kadar şaşırdım ki [...]"

"Ö.42 [...] arkadaşlarım deiğer kitaplara çalıșıyorlara rağmen ben onlara bakmıyorum."

"Ö.44 Nihayet sınavlar zor olmalarına rağmen benim için çok kolay olmuş."

"Ö.48 "[...] çalışmadan, çaba göstermeden hiçbir yere gitmez ve asla başarılı olamaz." gibi bir şey öğretmediler mi size?”

"Ö.56 O arkadaşım çocukluğumdan beri beraber büyüdük. [...] Bir andan sonra en yakın arkadaşım oldu."

Ana dili ya da yabancı dil olarak Türkçe öğretimi üzerine yapılan çalışmalarda dil bilgisi bağdaşıklığı ögelerinden en sık kullanılanı bağlama ögeleridir. Bilhassa yabancı dil 
olarak Türkçe öğreniminde Arapça gibi ana dili etkisinin ön plana çıkabileceği gerçekliği göz ardı edilemez. Ancak varlıkları ve yargıları bağlama aracı olarak anlam ilgilerini kurgulamada bağlaç ve edatların yaygın bir şekilde kullanımı ilgi çekicidir. Her ne kadar sınırlı sayıda olsa da anlam çeşitliliğini sağlama bakımından dil kullanıcısına ifade zenginliği sağlayan bağlaçların sık kullanımı, bu çalışmada olduğu gibi alan yazınında yer alan başka çalışmalarla da saptanmıştır. Seçkin vd. (2014, s. 340-353)'nin ekleyici, ayırt edici, zitlık, siralama, koşul, açıklama, örnekleme, sebep-sonuç başlıklarıyla ele aldıkları bağlama ögeleri 9., 11. sınıf ile üniversite 1. ve 3. sınıfların yazdıkları öykülerde en çok kullanılan dil bilgisi bağdaşıklı̆̆ ögesidir. Can'ın 2012 yılında tamamladığı doktora tezinde 9. ve 10. sınıf öğrencilerinin yazılı anlatımlarında paragraf düzeyinde bağdaşıklık incelenmiş ve dil bilgisi bağdaşıklığı ögeleri içinde en çok kullanılanın bağlama ögeleri $(\% 20,22)$ olduğu saptanmıştır. Keklik ve Yılmaz (2013, s. 139-157), 11. sınıfların yazdıkları metinleri incelemişler ve bağdaşıklık aracı olarak en çok bağlama ögelerinin kullanıldığı bulgusunu elde etmişlerdir. Muhakkak ki yaş grupları ve öğrenim kademelerine göre bağdaşıklık araçlarının kullanım oranlarında değişiklik söz konusu olabilmektedir. Ayrıca hangi türde metin yazıldığı yani yazılı verinin hangi metin türünden elde edildiği de önemli bir husustur. Bağdaşıklık araçlarının kullanım sıklığını etkileyen diğer bir durum ise söz konusu dilin ana dili olarak $\mathrm{m} 1$ yabancı dil olarak $\mathrm{m} 1$ öğretildiği gerçekliğidir. Yıldırım (2016, s. 78)'ın B1 düzeyinde Türkçe öğrenen yabancı öğrencilerle yaptığı çalışmada bağlama ögeleri, \%41 oranıyla en sık kullanılan bağdaşıklık aracı olarak saptanmıştır.

Tablo 6

Sözcük Bağdaşıklı̆̆1

\begin{tabular}{lcc}
\hline & $\mathrm{f}$ & $\%$ \\
\hline Tekrar & 138 & 63,59 \\
Aynı Kavram Alanı & 79 & 36,41 \\
\hline TOPLAM & & 100 \\
\hline
\end{tabular}

Tablo 6'da görüldüğ̈̈ gibi öğrencilerin yazdıkları öykülerde, kelime bağdaşıklığı olarak tekrara \%63,59, aynı kavram alanına giren sözcük kullanımına ise \%36,41 oranında başvurulmuştur.

"Ö.11 Bir hafta boyunca yorgun ve bitkin bir şekilde yatakta kaldım. [...] Telașlı olduğumu görünce bana düșünceli halimin sebebini sordu."

"Ö.18 Yemek hazırladım ve akşam yemeği yedik. [...] Ben erken kalktım ve ders çalıştım."

"Ö.50 Benim telefonum çaldı $[\ldots]$ çünkü telefonu almadım $[\ldots]$ sonra benim telefonum tekrar çaldı $[. .$.$] telefonu alacağım sirada..."$

"Ö.1 Çünkü dedeleri neneleri amcaları dayıları Musulda yaşıyorlar."

"Ö.7 Bütün duyguları bir anda hissettim adeta. Șaşırma, üzüntü, sevinç korku."

$\mathrm{Bu}$ çalışmada bütün bağdaşıklık araçları içinde sözcük bağdaşıklığı kullanım oranı \%8.81, kâğı̆ başına düşen sözcük bağdaşıklığı oranı 3,61'dir. Sözcük bağdaşıklığına yönelik bulgular, ana dili üzerine yapılan çalışmalarla tezat veriler arz etmektedir. Örneğin Can (2012, s. 126)'ın çalışmasında 9. ve 10. sınıfların yazılı anlatımlarının paragraf düzeyinde bağdaşıklık görünümleri hususunda sözcük bağdaşıklığının \%51,26 ile en sık kullanılan bağdaşıklık türü olduğu görülmektedir. Ancak yabancı dil öğretimi üzerine yapılan çalışmalardaki veriler, sözcük bağdaşıklığının kullanım oranının az olduğunu göstermektedir. Örneğin Ramadan (2003) İngilizce öğretimi üzerine yaptığı çalışmada, Ürdün devlet okullarındaki 12. sınıf öğrencilerinin yazılı anlatımlarında kâğıt başına sözcük bağdaşıklığı oranının \%1,63 olduğunu 
belirlemiştir. Yıldırım'ın (2016, s. 80) B1 düzeyinde Türkçe öğrenen öğrencilerle yaptığ çalışmada ise bu oran \%7,4'tür. Dolayısıyla bu verilerin araştırmada elde edilen verilerle örtüşür nitelikte olduğu söylenebilir.

Tablo 7

Bağdaşıklık Ögeleri

\begin{tabular}{|c|c|c|c|c|c|}
\hline & & & & $\mathrm{f}$ & $\%$ \\
\hline \multirow{12}{*}{ 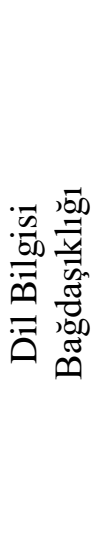 } & \multirow{12}{*}{$\begin{array}{l}2 \\
\vec{a} \\
\dot{a}\end{array}$} & & Kişi Zamiri & 510 & 20,73 \\
\hline & & Gönderim & Dönüşlülük Zamiri & 37 & 1,5 \\
\hline & & $\% 35,35$ & İşaret Zamiri & 51 & 2,1 \\
\hline & & & İşaret S1fat1 & 195 & 7,93 \\
\hline & & & İsme Dayalı & 6 & 0,24 \\
\hline & & 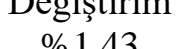 & Fiile Dayalı & 4 & 0,16 \\
\hline & & & Cümleye Dayalı & 22 & 0,89 \\
\hline & & & Özne & 346 & 14,07 \\
\hline & & Eksilti & Tümleç & 59 & 2,39 \\
\hline & & $\% 25,77$ & Nesne & 32 & 1,3 \\
\hline & & & Tamlayan & 141 & 5,73 \\
\hline & & Bağlama & Bağlaç & 554 & 22,52 \\
\hline \multirow{3}{*}{ 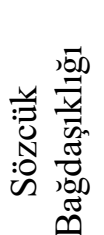 } & & $\% 37,45$ & Edat & 286 & 11,63 \\
\hline & \multirow{2}{*}{$\begin{array}{l}\infty \\
\infty \\
\infty \\
\infty\end{array}$} & \multirow{2}{*}{\multicolumn{2}{|c|}{$\begin{array}{l}\text { Tekrar } \\
\% 63,59 \\
\text { Aynı Kavram Alanı } \\
\% 36,41\end{array}$}} & 138 & 5,6 \\
\hline & & & & 79 & 3,21 \\
\hline & \multicolumn{3}{|r|}{ TOPLAM } & 2460 & 100 \\
\hline
\end{tabular}

Tablo 7'de görüldüğü gibi öğrencilerin yazdıkları öykülerde dil bilgisi bağdaşıklı̆̆1 $(\% 91,19)$, sözcük bağdaşıklığına (\%8.81) nazaran çok daha sık kullanılmıştır. Yazılı verilerde söz varlığı ve anlama kıyasla biçim ögelerinin ön planda olması ve bağdaşıklığın bu yolla sağlanması ilgi çekicidir. Muhakkak ki iletişimi sağlayan ve metinde bütünlüğü oluşturan birimler olarak dil bilgisi bağdaşıklığı ögeleri kullanılmaktadır. Öğretimde de buna öncelik verilmesi doğaldır. Ancak metinlerde varlık / kavram karşılayıcılarının kullanımına yönelik aynı oranda bir gelişmenin görülmemesi dikkat çekicidir. Bu araştırmada, çalışma grubunu oluşturan ve yabancı dil olarak Türkçe öğrenen öğrencilerin yazdıkları öykülerde; kelimenin aynen tekrar edilmesi, eş veya yakın anlamlı sözcük kullanımı, üstterim - alt anlamlılık içeren sözcük kullanımı, aynı kökten türemiş farklı sözcük kullanımı ile gerçekleştirilen tekrar ile aynı kavram alanında sözcüklerin kullanımına yönelik veriler, çok daha sınırlı sayıda olan dil bilgisel bağdaşıklık ögelerine nazaran daha az kullanılmıştır. Öte yandan dil bilgisi bağdaşıklığını sağlayan ve sınırlı sayıda olan birimlerin öğrenci öykülerinde tespit edilen kullanımlarında, hatalı kullanımın oldukça az olması da ilgi çekici bir veridir.

\section{Sonuç ve Öneriler}

$\mathrm{Bu}$ araştırmada Çukurova Üniversitesi Türkçe Öğretimi Uygulama ve Araştırma Merkezi ile Adana Bilim ve Teknoloji Üniversitesi Türkçe Öğretimi Uygulama ve Araştırma Merkezinden B1 yeterlilik düzeyinde olan 60 öğrenciden öykü tamamlama yoluyla elde edilen metinlerdeki bağdaşıklık ögelerine yer verme durumları değerlendirilmiştir. Çalışma sonucunda bağdaşıklık araçlarının her on kullanımından yaklaşık dokuzunun dil bilgisi bağdaşıklı̆̆ı, birinin ise sözcük bağdaşıklığı ögesi olduğu görülmektedir. Bu hususta, yabancı dil olarak Türkçe öğrenicisinin yazma gibi aynı anda birden çok dil kullanım biçimini (fikir, tasarlama, ifade yöntemi seçme, yazım kurallarına uyma, dil bilgisi ilkelerini göz önünde bulundurma vb.) kullanması gerektiği bir uygulamada dil bilgisi kullanımına özen gösterip anlamı ve onunla ilgili çeşitliliği 
sınırlaması ve metinde ifade zenginliğini yalnızca dil bilgisi bağdaşıklığı araçlarıyla sağlamaya çalışmasının söz konusu olduğu söylenebilir.

Dil bilgisi bağdaşıklığı araçlarından en çok kullanılanı bağlama ögeleridir. Öğrenci öykülerindeki üç bağlama ögesi tanığından ikisi bağlaç, biri edatlarla kurulandır. Kelimeleri, kelime gruplarını ve cümleleri türlü anlam ilgileriyle birbirine bağlayan ve ifade bütünlüğünü sağlayan bağlama ögelerinin bu çalışma kapsamındaki öykülerde işlev ve anlamına uygun olarak kullanıldığı, Türkçenin yabancı dil olarak öğretiminde söz konusu unsurların öğretiminde başarı sağlandığı söylenebilir.

Her ne kadar sınırlı türevleri bulunsa da gönderim araçları, bağlama ögelerinden sonra öğrenci öykülerinde en sık kullanılan dil bilgisi bağdaşıklığı ögeleridir. İsimlerin tekrarını engellemek ve metin içi birimler arası gönderimi sağlamak için kullanılan bu unsurların öykülerde art arda kullanımları, ifadede farklı bir sorunu doğurmuştur. Bu ögelerin kullanım sıklığının artması anlatımı kısırlaştırmıştır.

Eksiltili anlatım, Türkçenin ifade yöntemlerinden biridir. Öğrencilerin yazdıkları öykülerde eksilti türlerinden en çok özne eksiltmesini kullandıkları görülmektedir. Tamlayıcılar, yüklemde belirtilen sınırsız ifadenin, bireyin iletmek istediği meramına yönelik olarak sınırlandırma yapabilmesini sağlayan unsurlardır. Özne ise tamlayıcılardan farklı olarak yüklemde doğrudan yer alabilen bir ögedir. Türkçede bu nedenle öznenin tekrarından kaçınılması söz konusudur. Yabancı dil olarak Türkçe öğrenen öğrencilerin metinlerinde bu duruma sıkça rastlanması dil gerçekliğiyle örtüşmektedir. Bağdaşıklık ile ilgili alan yazınındaki diğer çalışmaların genelinden farklı olarak bu araştırmada, yüklem eksiltili biçim örneği de ele alınmıştır.

Çalışma grubunu oluşturan öğrencilerin yazdıkları öykülerde yer alan dil bilgisi bağdaşıklığı ögeleri içinde en az değiştirimin kullanıldığı görülmektedir. Hem ana dili hem de yabancı dil olarak Türkçe öğrenenlerle yapılan çalışmalardaki bulgular ile bu çalışmanın bulguları örtüşmektedir. Sınırlı sayıda olan değiştirim ögelerinin kullanım sıklığı da düşüktür.

Öğrenci öykülerinde sözcük bağdaşıklığı bakımından en çok tercih edilen bağdaşıklık ögesi; eş / yakın anlamlı, zıt anlamlı, aynı ya da kökteş kelimelerin yinelenmesini içeren tekrardır. Öğrenci öykülerinde her üç sözcük bağdaşıklığı örneğinden yaklaşık ikisi tekrar, biri aynı kavram alanına giren sözcük kullanımıdır.

$\mathrm{Bu}$ araştırma kapsamında elde edilen bulgular ışığında şu önerilerde bulunulabilir:

- Eş/yakın anlamlı kelimeler, zıt anlamlı kelimeler, aynı kökten türeyen kelimelerin, kavram alanı oluşturan ifadelerin iletişim aracı olarak kullanımına önem verilmesi dil öğrenicilerinin öğrendikleri dilin ifade zenginliğini sezmelerini sağlayacaktır. Bu bağlamda yabancı dil olarak Türkçenin öğretiminde kavram karşılayıcısı olarak söz varlı̆̆ının kullanımında çeşitliliğin kazandırılması gerekmektedir.

- Yabancı dil olarak Türkçe öğretiminde, yazma becerisinin geliştirilmesine yönelik çalışmalarda dil bilgisine dayanan unsurların kullanımı yoluyla metnin nasıl yazılacağının öğretilmesi kadar içeriği belirleyecek söz varlığı zenginliğinin kazandırılması ve uygulamalarda kelimeler arasındaki türlü anlam ilişkileri üzerinde durularak yer verilmesi gerekmektedir.

- Bağdaşıklığın dili iletişim aracı olarak kullanmada temel bir araç olduğunu hissettirmek için kelime, kelime grubu, cümle ve paragraflar arasındaki ilişkileri ya da metin bütünlüğüne katk1 sağlayan kullanımları göstermeye dayalı etkinliklere başvurulması gerekmektedir.

- Her ne kadar ana dili ve yabanci dil olarak Türkçe öğretiminde kişi zamirleri önemli ve yüksek sıklık sahibi ögeler olsalar da bunların tekrarlarının Türkçe anlatım ürünlerinde ifadeyi hantallaştırdığı sezdirilmelidir. Metin içi böylesi sık tekrarlardan kaçınılması sağlanmalıdır. Eksilti, gönderimi yapılan varlığın farklı şekilde anılması vb. yöntemler alternatif olarak öne çıkarılabilir.

- Bağdaşıklığın gerek dil bilgisi ögeleriyle gerekse kelime bağdaşıklı̆ğ üzerinden geliştirilmesi amacıyla Türkçe öğretimi kitaplarında özellikle söz varlığını öne 
çıkaracak, bir varlığın farklı kelime veya kelime gruplarıyla ifade edilebileceğini gösterecek uygulamalar yapılabilir. Benzer çeşitlilik, özellikle bağlama ögeleri gibi daha çok alternatifi olan dil bilgisi unsurları için de sağlanabilir.

\section{Kaynaklar}

Açık, F. (2008, Mart). Türkiye'de yabancılara Türkçe öğretilirken karşılaşılan sorunlar ve çözüm önerileri. 1. Uluslararası Türkçe Eğitimi ve Öğretimi Sempozyumu Bildirileri, Doğu Akdeniz Üniversitesi, Gazimağusa, Kıbrıs.

Ada, S. ve Şahenk Erkan, S. S. (2010). Avrupa dil portfolyosu ve Türkiye'de yabancı dil eğitimi. Marmara Avrupa Araştırmaları Dergisi, 18(1-2), 63-88.

Aksan, D. (2000). Her yönüyle dil ana çizgileriyle dilbilim (2. bs.). Ankara: Türk Dil Kurumu Yayınları: 439.

Aksan, M. ve Aksan, Y. (1991). Metin kavramı ve tanımları. Dilbilim Araştırmaları Dergisi, 2, 90-104.

Alan, Y. (1994). Lisan ve insan. İzmir: TÖV Yayınları.

Aramak, K. (2016). Türkçenin yabancı dil olarak öğretiminde bağdaşıklık araçlarının kullanım düzeyi üzerine bir araştırma (Yayımlanmamış yüksek lisans tezi). Gazi Üniversitesi Eğitim Bilimleri Enstitüsü, Ankara.

Ayata Şenöz, C. (2005). Metindilbilim ve Türkçe. İstanbul: Multilingual.

Ayaz, F. (2007). Ankara ilinde lise birinci sınıf öğrencilerinin yazılı anlatım becerilerinin içyapı bakımından gelişimi üzerine bir inceleme (Yayımlanmamış yüksek lisans tezi). Gazi Üniversitesi Eğitim Bilimleri Enstitüsü, Ankara.

Aytaş, G. (2008). Çağdaş gelişmeler ışı̆̆ında şiir tahlilleri. Ankara: Akçăg.

Banguoğlu, T. (1995). Türkçenin grameri. Ankara: Türk Dil Kurumu Yayınları: 528.

Beaugrande, R. ve Dressler, W. (1981). Introduction to text linguistic. London: Longman Group Company.

Biçer, N., Çoban, İ. ve Bakır, S. (2014). Türkçe öğrenen yabanc1 öğrencilerin karşılaştığı sorunlar: Atatürk Üniversitesi örneği. Uluslararası Sosyal Araştırmalar Dergisi, 7(29), $125-135$.

Can, R. (2012). Ortaöğretim öğrencilerinin yazılı anlatımlarında paragraf düzeyinde bağdaşıklık ve tutarlılık (Yayımlanmamış doktora tezi). Gazi Üniversitesi Eğitim Bilimleri Enstitüsü, Ankara.

Can, R. (2014). Ortaöğretim öğrencilerinin bağdaşıklık araçlarını işlevlerine göre yazılı anlatımlarında kullanma becerileri. Erzincan Üniversitesi Eğitim Fakültesi Dergisi, $16(2), 1-25$.

Çoban, A. ve Karadüz, A. (2015). 7. sınıf öğrencilerin öyküleyici metinlerinin bağdaşıklık ve tutarlılık ölçütlerine göre değerlendirilmesi. Adiyaman Üniversitesi Sosyal Bilimler Enstitüsü Dergisi, 8(19), 67-96.

Council of Europe (2000). A common European framework of reference for languages: learning, teaching, assessment. Strasbourg: Language Policy Unit.

Deny, J. (1941). Türk dili grameri- Osmanlı lehçesi, A. U. Elöve (Çev.). İstanbul Maarif Matbaas1.

Dilidüzgün, Ş. (2015). Eylem odaklı yaklaşım bağlamında yabancı dil olarak Türkçe öğretiminde yazma etkinlikleri. Journal of Language Education and Research, 1(2), 1634.

Ergin, M. (2009). Türk dil bilgisi. İstanbul: Bayrak Basım/Yayım/Tanıtım.

Gencan, T. N. (1979). Dilbilgisi. Ankara: Türk Dil Kurumu Yayınları: 418.

Göçer, A. (2011). Öğrencilerin yazılı anlatım çalışmalarının Türkçe öğretmenlerince değerlendirilmesi üzerine. Ondokuz Mayıs Üniversitesi Ĕ̆itim Fakültesi Dergisi, 30(2), 71-97.

Göktürk, A. (1988). Okuma uğraşı. İstanbul: İnkılâp Kitabevi.

Günay, D. (2003). Metin bilgisi (Genişletilmiş 2. bs.). İstanbul: Multilingual.

Halliday M. A. K. ve Hasan R. (1976). Cohesion in English. London: Longman. 
Hannel, G. (2008). Success with Inclusion 1001 teaching strategies and activities that really work. Canada: Routledge.

Hatiboğlu, V. (1982). Dilbilgisi terimleri sözlüğü. Ankara Üniversitesi Dil ve Tarih Coğrafya Fakültesi Yayınları: 276.

Kara M. (2010). Gazi Üniversitesi TÖMER öğrencilerinin Türkçe öğrenirken karşılaştıkları sorunlar ve bunların çözümüne yönelik öneriler. Türk Eğitim Bilimleri Dergisi, 8(3), 661-696.

Karaağaç, G. (2013). Dil bilimi terimleri sözlüğü. Ankara: Türk Dil Kurumu.

Karababa, Z. C. C. (2009). Yabancı dil olarak Türkçenin öğretimi ve karşılaşılan sorunlar. Ankara Üniversitesi Eğitim Bilimleri Fakültesi Dergisi, 42(2), 265-277.

Karabağ, S. ve İşsever, S. (1995). Edinim sürecinde bağdaşıklık. IX. Dilbilim Kurultayl, 25-27 Mayls 1992, Bolu, Türkiye, Bildiriler içinde (s. 221-235). Bolu: Abant İzzet Baysal Üniversitesi Yayınları.

Karadeniz, A. (2015). Metin dil bilimi temelli metin çözümlemesinin bağdaşıklık araçlarını kullanma ve tutarlı metin oluşturma becerilerine etkisi. Mersin Üniversitesi Ë̆itim Fakültesi Dergisi, 11(1), 1-17.

Karatay, H. (2010). Bağdaşıklık araçlarını kullanma düzeyi ile tutarlı metin yazma arasındaki ilişki. Mustafa Kemal Üniversitesi Sosyal Bilimler Enstitüsü Dergisi, 7 (13), 373-385.

Keçik, İ. ve Uzun, L. (2003). Türkçe yazılı ve sözlü anlatım. Eskişehir: Anadolu Üniversitesi Yayınları.

Keklik, S. ve Y1lmaz, Ö. (2013). 11. sınıf öğrencilerine ait öyküleyici metinleri bağdaşıklık ve tutarlılık açısından incelenmesi. Uşak Üniversitesi Sosyal Bilimler Dergisi, 6(4),139157.

Korkmaz, Z. (1992). Gramer terimleri sözlüğü. Ankara: Türk Dil Kurumu Yayınları: 575.

Korkmaz, Z. (2009). Türkiye Türkçesi grameri-şekil bilgisi. Ankara: Türk Dil Kurumu Yayınlar1: 827.

Li, Yong Sŏng (2004). Türk dillerinde sontakılar. İstanbul: Türk Dilleri Araştırmaları Dizisi: 40.

Maden, S. ve İşcan, A. (2011). Yabancı dil olarak Türkçe öğretimi amaç ve sorunlar: Hindistan örneği. Karadeniz Sosyal Bilimler Dergisi, 5, 23-38.

Maden, S., Dinçel, Ö. ve Maden, A. (2015). Türkçeyi yabancı dil olarak öğrenenlerin yazma kaygıları. Uluslararası Türkçe Edebiyat Kültür Ĕ̈itim Dergisi, 4(2), 748-769.

Oraliş, M. ve Ozil, Ş. (1992). Metindilbilimsel yaklaşımla yazınsal bir metni çözümleme denemesi. Dilbilim Araştırmaları Dergisi. Erişim adresi: http://dergipark.ulakbim. gov.tr/dad/issue/view/5000012618

Özmen, M. (1987). da/de bağlama ve kuvvetlendirme edatının türeyişi. Selçuk Üniversitesi Edebiyat Fakültesi Dergisi, 4, 73-79.

Özmen, M. (2013). Türkçenin sözdizimi. Adana: Karahan Kitabevi.

Ramadan, S. M. S. (2003). Cohesion in written works of the twelfth grade students of literary and scientific streams at state secondary schools in jordan (Yayımlanmamış doktora tezi). Gazi Üniversitesi Eğitim Bilimleri Enstitüsü, Ankara.

Said, H. A. (1988). The cohesive role of reference, subsitituon and ellipsis in two genres of modern literary Arabic (Unpublished doctorate thesis). Texas A\&M University, Texas.

Seçkin, P., Arslan, N. ve Ergenç, S. (2014). Bağdaşıklık ve tutarlılık bakımından lise ve üniversite öğrencilerinin yazılı anlatım becerileri. Uluslararası Türkçe Edebiyat Kültür Eğitim Dergisi, 3(1), 340-353.

Stotsky, S. (1983). Types of lexical cohesion in expository writing: Implications for developing the vocabulary of academic discourse. College composition and communication, 34(4), 430-446.

Tekin, T. (1958). Türeme bilgisi araştırmalanı: da/de bağlayıcısının türeyişi. Türk Dili ve Edebiyatı Dergisi, 7(78), 276-277.

Ungan, S. (2007). Yazma becerisinin geliştirmesi ve önemi. Erciyes Üniversitesi Sosyal Bilimler Enstitüsü Dergisi, 461-472. 
Üstünova, K. (2002). Dil yazıları. Ankara: Akçağ Yayınları.

Uzun, L. S. (1995). Orhun yazıtlarının metindilbilimsel yapısı. Ankara.

Vardar, B. (2002). Açıklamalı dilbilim terimleri sözlüğü. İstanbul: Multilingual.

Yalçın, A. (2002). Türkçe öğretim yöntemleri - yeni yaklaşımlar. Ankara: Akçağ Yayınları.

Yıldırım, A. ve Şimşek, H. (2005). Sosyal bilimlerde nitel araştırma yöntemleri (2. bs.). Ankara: Seçkin Yayıncılık.

Yıldırım, S. (2016). B1 düzeyinde Türkçe ögrenen yabancıların yazılı anlatımlarının bağdaşıklık düzeyleri (Gazi Tömer örneği) (Yayımlanmamış yüksek lisans tezi). Gazi Üniversitesi Yabancı Dil Olarak Türkçenin Öğretimi Ana Bilim Dalı, Ankara.

\section{Extended Abtract}

\section{Introduction}

In the first studies carried out on the text, the text was observed as the coming together of lingual units and sentences in a particular order, and the elements ensuring the integrity of the text and the context of the text were disregarded (Uzun, 1995). In time, it was argued in the studies conducted in the field of linguistics that linguistic examinations carried out based solely on the sentence are insufficient, and it is necessary to turn towards relations beyond the sentence, i.e. to units that are larger than the sentence.

It is possible to distinguish a text from the one that is not a text by using various criteria when determining whether sentences in a text are suitable in terms of grammar according to grammar rules. Coherence and consistency are the most important ones among these criteria. Coherence means all the features related to a language that form intra-textual relations that turn a piece of writing into a text (Günay, 2003, p. 57). Since coherence and the elements that ensure coherence affect the process of creating a text and the quality of the writing skill, it is quite important in writing education specifically and in the process of teaching a language in general. Halliday and Hasan (1976) stated that coherence is ensured via elements or words based on grammar; therefore, they talked about grammatical coherence and lexical coherence.

As it is also expressed by Beaugrande and Dressler (1981) in writing education, it is necessary to consider coherence as the precondition of creating a text by assuming that grammar-based relations in the structure of the text are the basic requirement of the formation of a text, and to develop the quality of the relations based on coherence in texts written by students. The aim of the study conducted starting from this importance is to determine the outlook of the narrative texts written by students at the B1 level who learn Turkish as a foreign language in terms of coherence.

\section{Method}

This study was designed as a case study, and the document review method was used as a data collection method. Written materials were created by examining the narrative texts written by students learning Turkish as a foreign language within the scope of the study. The criterion sampling method among purposeful sampling methods was used within the scope of the study. The B1 level was determined as a criterion, and it was decided to collect data from students at the B1 level, and the study group consisted of 60 students at the B1 level.

The students were made to perform the story completion activity in order to collect the research data. It was attempted to determine the frequency at which students used the elements of coherence in narrative texts written by students. The content analysis was performed to this end. An evaluation form was created to be able to evaluate narrative texts, and the texts written by each student were evaluated in terms of including the coherence elements of the text. The example uses of each element of coherence in student texts were included by making direct quotations from texts. The study group was not selected from one institution; it was diversified by selecting it from two different institutions. Within the scope of this study, the text of each student was separately evaluated by two researchers in order to ensure reliability, the 
evaluations made by two researchers were compared, and it was observed that the evaluations made by the researchers matched at the rate of $98 \%$.

\section{Result and Discussion}

As a result of the study, it is observed that approximately nine of each ten uses of the tools of coherence are the elements of grammatical coherence, while one is an element of lexical coherence. In this sense, it can be said that in a practice in which a student learning Turkish as a foreign language needs to use more than one language usage forms at the same time such as writing (idea, design, selecting the method of expression, complying with the rules of writing, taking into consideration grammatical principles, etc.), care is taken about the use of grammar, restricting the meaning and the variety related to it, and trying to ensure the richness of expressions in the text only by using the tools of grammatical coherence are in question.

The most widely used grammatical coherence tool is the elements of connection. Among three elements of connection in student narrations, two of them are those formed with conjunctions, and one of them is the one formed with prepositions. It can be said that the elements of connection that connect words, word groups and sentences with each other with various meaning relevance and ensure the integrity of expression are used in accordance with the function and meaning in the stories within the scope of this study, and success is achieved in the teaching of the elements in question in teaching Turkish as a foreign language.

Although they have limited derivatives, reference tools are the most widely used grammatical coherence elements in student narrations following the elements of connection. The findings obtained from student narrations within the scope of the study match up with the studies conducted on the teaching of Turkish as a mother tongue. According to the findings obtained from the study conducted by Seçkin, Arslan and Ergenç (2014, p. 346), the reference elements that are most widely used by students are listed according to their frequencies as follows: personal pronoun (1004), demonstrative adjective (408), demonstrative pronoun (161) and reflexive pronoun (70). Yildirım (2016, p. 76) determined that personal pronouns (45\%) are the most widespread reference element in the written narrations of the foreigners learning Turkish. Demonstrative pronouns were used at a rate of $23 \%$, demonstrative adjectives were used at a rate of $13 \%$, and reflexive pronouns were used at a rate of $3 \%$.

The elliptical expression is among the methods of expression in Turkish. It is observed that students use subject ellipsis at most among the types of ellipsis in the narrations written by students. Modifiers are the elements that allow the unlimited expression stated in the predicate to make limitations on the intent of the individual.

It is observed that substitution is used at least among the elements of grammatical coherence in the narrations used by the students that make up the study group. The findings of this study match up with the findings of the studies carried out with the learners of Turkish both as a mother tongue and as a foreign language. The usage frequency of the elements of substitution that are limited in number is also low. Karabağ and İşsever (1995, p. 221-235) did not determine the elements of substitution in the study they conducted with children at the ages between 48 and 60 months. Yildirim (2016, p. 77) determined that the elements of substitution are scarcely any in the texts written by the foreigners learning Turkish. The average of the elements of substitution in the study of Yildirım per participant is $0.14 \%$. Similar results are obtained in the studies in which the elements of coherence are examined in languages other than Turkish. Ramadan (2003) who studied the texts written in English by $12^{\text {th }}$-grade students in Jordan failed to determine substitution among the elements of coherence.

The element of coherence that is most widely preferred in student narrations in terms of lexical coherence is repetition, which includes the repetition of synonymous/near-synonymous, antonymous, same or cognate words. Two of all three lexical coherence examples in student narrations are repetition, and one is the use of the word that is included within the same concept area. 